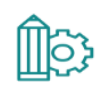

GUÍA PRÁCTICA DE

INSTALACIÓN DE TIENDA

\title{
ELECTRÓNICA CON
}

\section{PRESTASHOP VERSIÓN}

\subsubsection{2}

Diana María Robayo Botiva

Universidad Cooperativa de Colombia

Sede Villavicencio

\author{
Documentos de docencia | Course Work \\ coursework.ucc.edu.co \\ No. 12 , noviembre de 2018 \\ doi: https://doi.org/10.16925/gcgp.03
}

\section{NOTA LEGAL}

El presente documento de trabajo ha sido incluido dentro de nuestro repositorio de literatura gris por solicitud del autor, con fines informativos, educativos o académicos. Asimismo, los argumentos, datos y análisis incluidos en el texto son

responsabilidad absoluta del autor y no representan la opinión del Fondo Editorial o de la Universidad.

\section{DISCLAIMER}

This coursework paper has been uploaded to our grey literature repository due to the request of the author. This document should be used for informational, educational or academic purposes only. Arguments, data and analysis included in this document represent authors' opinion not the Press or the University. 


\section{Acerca de la autora}

Diana María Robayo Botiva, magíster en Comercio Electrónico del Instituto Tecnológico y de Estudios Superiores de Monterrey, profesora de la Facultad de Ciencias Económicas Administrativas y Contables, Universidad Cooperativa de Colombia, sede Villavicencio, Colombia.

Correo electrónico: diana.robayo@campusucc.edu.co

\section{Cómo citar este documento}

Robayo-Botiva, D. M. (2018). Guía práctica de instalación de tienda electrónica con Prestashop versión 1.7.4.2. (Documento de docencia $\mathrm{N}^{\circ}$ 12). Bogotá: Ediciones Universidad Cooperativa de Colombia, 2018. doi: https://doi.org/10.16925/gcgp.03

Este documento puede ser consultado, descargado o reproducido desde nuestro repositorio de documentos de trabajo (http://coursework.ucc.edu.co) para uso de sus contenidos, bajo la licencia de Creative Commons Reconocimiento-NoComercial-SinObraDerivada 4.0 Internacional. http://creativecommons.org/licenses/by-nc-nd/4.0/ 


\section{Resumen}

Internet no solo permite la interacción entre los internautas, también se ha convertido en un espacio para el surgimiento de nuevos modelos de negocio e ingresos. Los nuevos modelos de negocio e ingresos han surgido de ideas innovadoras de emprendedores que han visto en Internet una oportunidad financiera real. Además, también las empresas tradicionales lo han aprovechado para ampliar sus canales de venta y lograr así una mayor ventaja competitiva. A su vez, pequeñas empresas han encontrado una forma de promocionar y vender sus productos y servicios a través de sitios de redes sociales o con la implementación de tiendas electrónicas. En consecuencia, Internet ha transformado en parte la forma de hacer negocios. Respecto a las tiendas electrónicas, existe una gran variedad de proveedores, los cuales ofrecen implementación por un costo mensual, semestral y anual (dependiendo también de sus funcionalidades). Asimismo, existen sitios que admiten descargarla de forma gratuita (con algunas limitaciones) y desarrollarla localmente para su posterior implementación en línea. Así, entonces, en el curso de "Comercio y negociaciones virtuales y sistemas de información gerencial en las organizaciones" se motiva a los estudiantes, como práctica, a la instalación local de una tienda electrónica mediante su ajuste conforme a la matriz de valoración entregada por el docente (proyecto de fin del semestre), lo cual es coherente con los temas de los cursos mencionados. Esta actividad promueve en los estudiantes junto con ideas de negocio la posibilidad de desarrollar su negocio en una plataforma totalmente en línea, así como ofrece ventajas en aspectos financieros y de promoción. No obstante, es importante consultar aspectos legales, de seguridad y manejo de pagos electrónicos.

Palabras clave: características del comercio electrónico, comercio electrónico, Prestashop, tiendas electrónicas, tipos de comercio. 


\section{Tabla de Contenido}

$\begin{array}{lr}\text { Introducción } & 8\end{array}$

$\begin{array}{lr}\text { Propósito de la práctica } & 8\end{array}$

$\begin{array}{ll}\text { Marco teórico } & 9\end{array}$

$\begin{array}{lr}\text { Comercio electrónico } & 9\end{array}$

$\begin{array}{lr}\text { Características únicas del comercio electrónico } & 9\end{array}$

Tipos de comercio electrónico de acuerdo con los actores que intervienen $\quad 10$

Tipos de comercio electrónico de acuerdo con el grado de digitalización 11

Marco de referencia del comercio electrónico 12

$\begin{array}{ll}\text { Tiendas electrónicas } & 12\end{array}$

¿Qué es una tienda virtual y cómo funciona? 13

$\begin{array}{ll}\text { Proveedores para implementación de tiendas electrónicas } & 14\end{array}$

$\begin{array}{lr}\text { Objetivos y materiales } & 20\end{array}$

$\begin{array}{ll}\text { Descripción de actividades y procedimientos de la práctica } & 21\end{array}$

Instalación de tienda electrónica $\quad 22$

Instalación de tienda prestashop $\quad 32$

Trabajo final para los estudiantes $\quad 46$

$\begin{array}{ll}\text { Referencias } & 48\end{array}$

Parámetros para la elaboración y presentación del informe 50 


\section{Índice de figuras}

Figura 1. Actores y tipos de comercio electrónico

Figura 2. Marco de referencia del comercio electrónico

12

$\begin{array}{ll}\text { Figura 3. Logo de Jimdo } & 14\end{array}$

$\begin{array}{ll}\text { Figura 4. Logo de GoDaddy } & 15\end{array}$

Figura 5. Logo de Jumpseller 16

Figura 6. Logo de Shopify 16

$\begin{array}{ll}\text { Figura 7. Logo de Webnode } & 17\end{array}$

$\begin{array}{ll}\text { Figura 8. Logo de Prestashop } & 17\end{array}$

Figura 9. Sitio de descarga XAMPP 22

Figura 10. Inicio instalación XAMPP, paso 1

Figura 11. Inicio instalación XAMPP, paso 2

Figura 12. Inicio instalación XAMPP, paso 3

Figura 13. Inicio instalación XAMPP, paso 4

Figura 14. Inicio instalación XAMPP, paso 5

Figura 15. Inicio instalación XAMPP, paso 6

Figura 16. Inicio instalación XAMPP, paso 7

$\begin{array}{ll}\text { Figura 17. Inicio instalación XAMPP, paso } 8 & 27\end{array}$

Figura 18. Inicio instalación XAMPP, paso 9

Figura 19. Vista icono de XAMPP en la barra de herramientas de Windows 28 
Figura 20. Panel de control de XAMPP

Figura 21. Configuración de XAMPP, paso 1

Figura 22. Creación de base de datos, paso 1

Figura 23. Creación de base de datos, paso 2

Figura 24. Creación de base de datos, paso $3 \quad 31$

Figura 25. Creación de base de datos, paso 4

Figura 26. Sitio de descarga de Prestashop 32

Figura 27. Recomendaciones para instalar Prestashop 33

Figura 28. Sitio donde se encuentra descargado Prestashop en el equipo 33

Figura 29. Inicio de descompresión de archivo en el equipo 34

Figura 30. Búsqueda de ruta para la descompresión del archivo de instalación 34

Figura 31. Ruta para la descompresión del archivo 35

Figura 32. Inicio de instalación de la tienda electrónica 36

Figura 33. Instalación de la tienda, paso 1

Figura 34. Instalación de la tienda, paso 2

Figura 35. Instalación de la tienda, paso 3

Figura 36. Instalación de la tienda, paso $4 \quad 38$

Figura 37. Instalación de la tienda, paso 5

Figura 38. Instalación de la tienda, paso $6 \quad 39$

Figura 39. Instalación de la tienda, paso $7 \quad 39$

Figura 40. Instalación de la tienda, paso $8 \quad 40$ 
Figura 41. Instalación de la tienda, paso 9

Figura 42. Finalización de la instalación $\quad 41$

Figura 43. Mensaje para borrado de carpeta "Install”

Figura 44. Ruta para la eliminación de la carpeta "Install" 42

Figura 45. Solicitud de logueo para entrar a la parte administrativa de la tienda 42

Figura 46. Datos para el logueo a la parte administrativa 43

Figura 47. Mensaje de bienvenida a la parte administrativa de la tienda Prestashop 43

Figura 48. Parte administrativa de la tienda Prestashop 44

Figura 49. Front end de la tienda electrónica 45 


\section{Introducción}

Entre los temas propuestos en el curso "Comercio y negociaciones virtuales, sistemas de información gerencial en las organizaciones" se encuentra el tema relacionado con el comercio electrónico. Por ende, se realiza una práctica de la instalación local de una tienda electrónica para el desarrollo del proyecto de fin de semestre, en la cual los estudiantes ajustaran lo que se refiere a impuesto, moneda, pagos, productos, envíos, ofertas, categorías y subcategorías. Estas se evaluarán con base en la matriz de valoración del profesor.

\section{Propósito de la práctica}

Instalación de una tienda electrónica para el desarrollo del proyecto de fin de semestre de los estudiantes de sistemas de información gerencial en las organizaciones y comercio y negociaciones virtuales. 


\section{Marco teórico}

\section{Comercio electrónico}

El comercio electrónico se refiere al uso de Internet, de la web, de las aplicaciones móviles y los browsers que corren en dispositivos móviles para la realización de transacciones de negocio. De manera más formal, son transacciones comerciales habilitadas de forma digital entre las organizaciones y los individuos. Las transacciones comerciales involucran un intercambio de valor (dinero) a través de los limites organizaciones $\mathrm{o}$ individuales en retorno a productos $\mathrm{y}$ servicios. El intercambio de valor es importante para entender los límites del comercio electrónico; sin intercambio de valor no ocurre el comercio (Laudon y Guercio, 2017).

\section{Características únicas del comercio electrónico}

Según Laudon y Guercio (2017) existen ocho características únicas del comercio electrónico:

- Ubiquidad. Disponible en cualquier lugar, a cualquier hora del día.

- Alcance global. Permite la realización de transacciones comerciales que traspasan los límites culturales, regionales y nacionales.

- Estándares universales. Los estándares en Internet se comparten con todas las naciones alrededor del mundo.

- Riqueza. La complejidad y el contenido de un mensaje.

- Interactividad. Tecnología que permite la comunicación en dos vías (entre consumidor y comerciante).

- Densidad de la información. Calidad en la información disponible de todos los participantes del mercado. 
- Personalización. Envío de mensajes promocionales acordes a los intereses de los consumidores, pero también, la posibilidad de ajustar el producto de acuerdo con las preferencias de los consumidores.

- Tecnología social. Los nuevos modelos de negocio y las redes sociales habilitan la creación y la distribución de contenido del usuario.

\section{Tipos de comercio electrónico de acuerdo con los actores que intervienen}

Los tipos de comercio electrónico se diferencian, principalmente, con base en los actores que participan en las transacciones, es decir, es posible diferenciar el comercio que se realiza según intervengan:

- Empresas.

- Consumidores.

- Administración pública.

De la interacción entre estos tres agentes podemos encontrar:

- Comercio entre empresas, también llamado "B2B" (sigla de business to business).

- Comercio entre empresas y consumidor, o también "B2C" (sigla de business to consumer).

- Comercio entre consumidores y empresa, también "C2B" (sigla de consumers to business).

- Comercio entre consumidores, o "C2C" (sigla de consumer to consumer). 
- Comercio entre empresa y administración, o "B2A" (sigla de business to administration).

El comercio entre administración y consumidor (C2A) es prácticamente inexistente, y se limita a algunas experiencias todavía en fase de pruebas para el pago de impuestos vía electrónica o la solicitud de información a los organismos públicos.

Las posibilidades de relación se presentan en la figura 1.

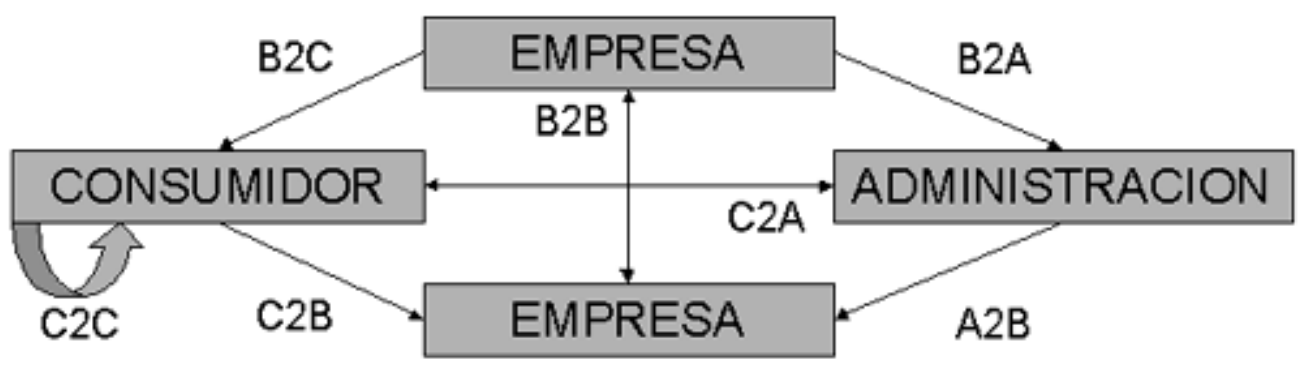

Figura 1. Actores y tipos de comercio electrónico. (UOC).

Fuente: Marketing Digital. (s. f). Actores y tipos de comercio electrónico. UOC.EDU. Recuperado de http://cv.uoc.edu/UOC/a/moduls/90/90_574b/web/main/m8/c5/2.html

\section{Tipos de comercio electrónico de acuerdo con el grado de digitalización}

El comercio electrónico puede tener muchas formas dependiendo el grado de digitalización, de las dimensiones: 1. El producto vendido; 2. El proceso; o 3. El agente de entrega (intermediario). Cuando las tres dimensiones son digitales se hace referencia al comercio electrónico puro; cuando alguna de ellas no es digital, se habla de comercio electrónico parcial (Turban y Volonino, 2010). 


\section{Marco de referencia del comercio electrónico}

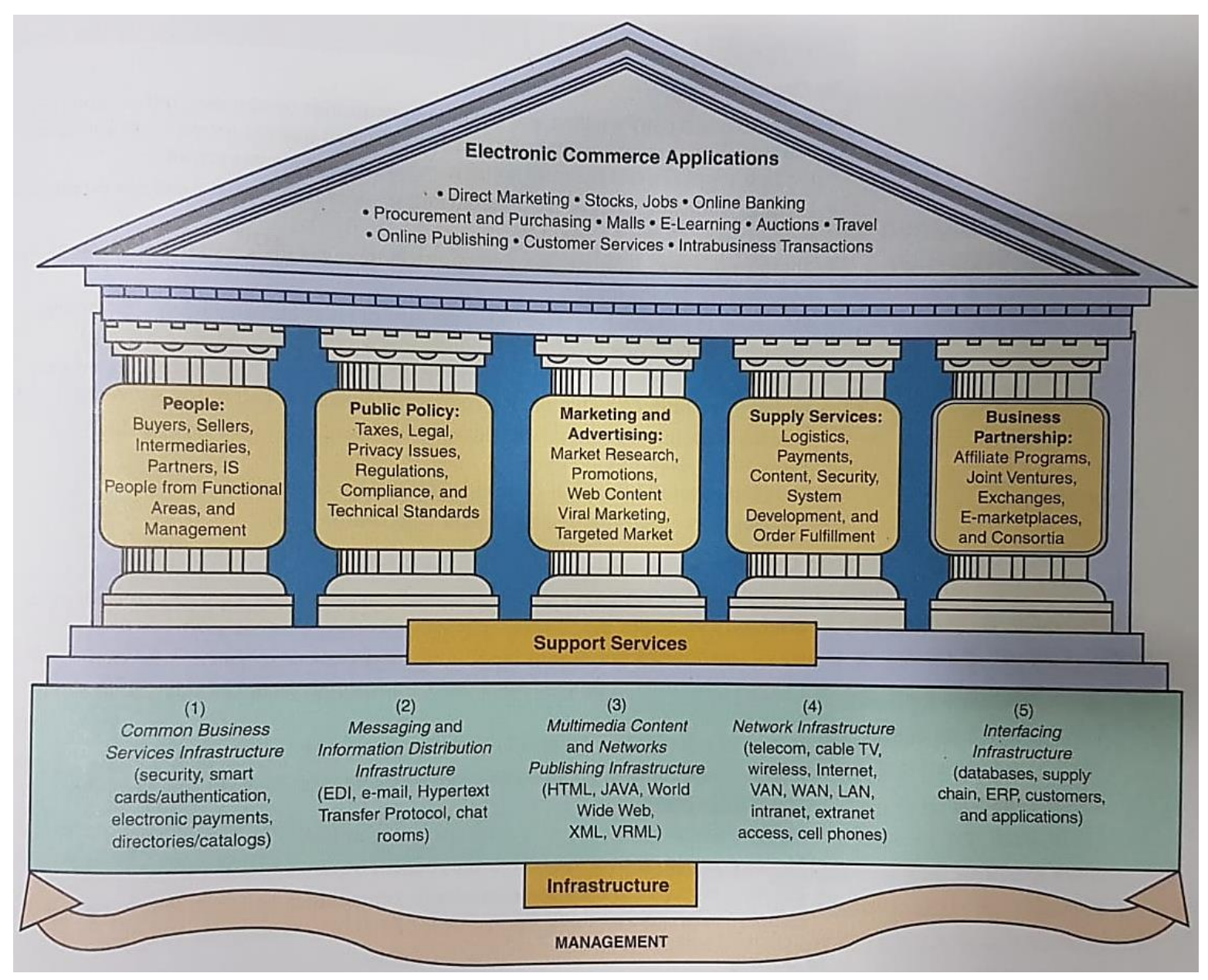

Figura 2. Marco de referencia del comercio electrónico ${ }^{1}$

Fuente: tomada de Turban, E. y Volonino, L. (2010). Information technology for management (7 ed.). Editorial Wiley.

\section{Tiendas electrónicas}

Peña (2016) indica que se denomina "tienda electrónica" todo sitio web que se dedica de forma exclusiva a la venta de productos a través de medios en línea. Forma parte

${ }^{1}$. En la parte superior del marco de referencia del comercio electrónico se encuentran las aplicaciones, en las cuales a su vez se encuentran las tiendas electrónicas 
fundamental de lo que conocemos como "comercio electrónico" y está en un gran apogeo en los últimos años.

Podemos mencionar varios ejemplos, pero el más popular de todos es Amazon, un sitio conocido internacionalmente y que se ha transformado en un modelo a seguir por otros e-commerce que quieren alcanzar el éxito en ventas.

\section{¿Qué es una tienda virtual y cómo funciona?}

Así como una tienda física, una tienda en línea requiere de un espacio para su instalación. Sin embargo, es esencial que exista cierto tipo de promoción. A diferencia de un espacio físico, las personas no podrán encontrar su tienda en el camino. El Internet es un universo extremadamente amplio en el que una página, si no cuenta con la publicidad adecuada, puede perderse en el limbo de la web.

\section{Proceso de compra.}

Una vez se cuenta con un lugar establecido y promocionado de forma correcta, el usuario que realice una compra en línea pasará por el siguiente proceso. Ingresará a la web, escogerá un producto del catálogo y seleccionará uno de los diferentes medios

de pago que debe tener disponible. Esta operación debe resultar fácil para el cliente, ya que tendrá mucha influencia en su experiencia de compra.

\section{Recepción de órdenes.}

Esta es la parte en la que la empresa se encarga de recibir todas las órdenes de compra y organizarlas bien para realizar las entregas. La gestión debe realizarse de la manera más eficiente para que no existan retrasos y los clientes queden totalmente satisfechos. 


\section{Envío de pedidos.}

Cuando se establece una tienda virtual es imprescindible que cuentes con un sistema de entrega capaz de satisfacer la demanda de tus clientes. Si no se logra cumplir con el tiempo de entrega prometido, toda la experiencia de compra quedará arruinada y se perderá la lealtad de las personas.

\section{¿Qué se necesita para crear una tienda electrónica?}

- Seleccionar una plataforma e-commerce.

- Seleccionar un dominio y un hosting.

- Elegir medios de pagos y servicio de entrega.

Debido a que nuestra práctica es la instalación local de una tienda electrónica, se profundizará solo en la selección de la plataforma e-commerce.

\section{Proveedores para la implementación de tiendas electrónicas}

En Internet existe una gran variedad de proveedores para el diseño e implementación de tiendas electrónicas. A continuación, se mencionan algunas:

Jimdo.

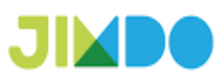

Figura 3. Logo de Jimdo

Fuente: tomado de https://bit.ly/2FWwZBX 
Es una plataforma en línea para crear páginas web y tiendas, también, en línea; además, todas las páginas web cuentan con una versión adaptada para móviles. Actualmente, cuenta con más de 12 millones de páginas web creadas. El sistema dispone de un conjunto de platillas en HMTL5 y CSS3 categorizadas en sectores como tiendas online, portafolios o servicios. Cada plantilla cuenta además con una serie de variantes que incluyen combinaciones de colores y de tipos de letra.

Jimdo dispone de tres versiones: JimdoFree, la versión gratuita; JimdoPro y JimdoBusiness, las cuales son las versiones profesionales que cuentan con más prestaciones como dominio propio, cuentas de correo electrónico o un soporte técnico más especializado (Jimdo, 2018).

\section{GoDaddy.}

\section{舀GoDaddy}

Figura 4. Logo de GoDaddy

Fuente: tomado de https://bit.ly/2Mv2hkJ

GoDaddy impulsa la plataforma de nube más grande del mundo dedicada a pequeñas empresas independientes. Con más de 17,5 millones de clientes en todo el mundo y la gestión de más de 76 millones de nombres de dominio, GoDaddy es el lugar al que acuden las personas para ponerle nombre a su idea, crear un sitio web profesional, atraer clientes y administrar su trabajo. Dentro de los sitios web que ofrece se encuentra: "Diseño de sitios web para comercio electrónico", denominada "Tienda web premium", y construida en Wordpress (Godaddy, 2018). 


\section{Jumpseller.}

\section{umpseller}

Figura 5. Logo de Jumpseller

Fuente: tomado de https://jumpseller.co/about/

Se fundó en el 2009 en Porto, Portugal. Se llamaba Vendder, en ese momento, y se lanzó la primera versión del producto Jumpseller en septiembre del 2010. Después de lanzar el producto creció rápidamente a miles de clientes. Jumpseller es la solución de comercio electrónico que le permite configurar una tienda en línea con solo unos pocos clics y comenzar a vender (Jumpseller, 2018).

\section{Shopify.}

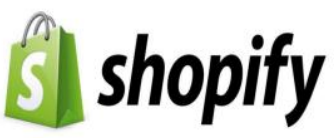

Figura 6. Logo de Shopify

Fuente: tomado de https://bit.ly/2FMJEYS

Shopify es un motor de comercio electrónico que te permite crear una tienda en línea sin conocimientos técnicos y sin tener que preocuparte por actualizaciones de plugins, versiones, servidores, etc. 
Con frecuencia, a este tipo de servicios en línea se les llama Saas (sigla de software as a services). Olvidarte de la tecnología te da la posibilidad de centrarte en lo más importante: conseguir clientes. Shopify te permite comenzar a vender en línea utilizando los mejores diseños en un tiempo record (Merodio, 2018).

\section{Webnode.}

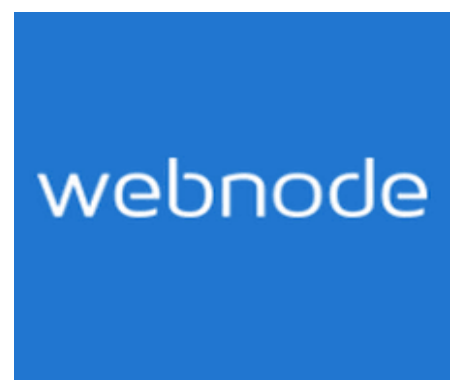

Figura 7. Logo de Webnode

Fuente: tomado de https://bit.ly/2FNJvEJ

Webnode es un creador de páginas web maravilloso por la sencillez de su uso. Desde su nacimiento en el 2008, ya ha ayudado a más de 30 millones de usuarios a crear sus propias páginas web. No importa si necesita una web profesional para negocio, un bonito portafolio o una tienda en línea intuitiva para los visitantes; tendrás la herramienta adecuada para crear una web como quieres (Webnode, 2018).

\section{Prestashop.}

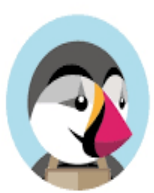

\section{PrestaShop}

Figura 8. Logo de Prestashop

Fuente: tomado de https://josefacchin.com/prestashop/ 
PrestaShop es un CMS o script realizado en PHP con licencia de código abierto (open source), pensado, principalmente, para diseñar tiendas en línea y gestionar la venta de productos en Internet. En su última versión, se ha reconstruido su core para complementarlo con el popular y potente framework llamado "Symfony". Dicho con otras palabras, es una plataforma o software gratuito que permite crear sitios sin programar (en este caso, tiendas en línea), es decir, un gestor de contenidos digitales que incluye un carrito de compra. Cuenta con un código de programación reconstruido que incorpora el constructor Symfony, de modo que si queremos tener un e-commerce profesional y no somos programadores, no hay mejor forma de hacerlo. Además, tiene todo lo necesario para realizar una tienda, sin apenas disponer de complementos extras o funcionalidades externas, ya que es un CMS orientado y creado $100 \%$ para la venta de productos en negocios en línea (Ortega, 2018).

Finalmente, para Calcaneo (2018) las plataformas que permiten crear tiendas en línea han llegado a ser tan populares que se pueden encontrar cientos de sitios web que ofrecen estos servicios. Algunas son plataformas simples para vender una cantidad baja de productos, otros se centran en empresas grandes en las que los artículos de ventas se inventarían por su volumen. Si se inicia apenas en el mundo del $e$-commerce, o quieres crear una tienda en línea, estos son algunos puntos que nunca debes dejar pasar:

- Tener una lista de los productos que se manejan en la tienda

- Vender productos y servicios, desde físicos hasta digitales.

- Que la tienda en línea siempre incluya un carrito de compras. De esta manera, los usuarios podrán ir añadiendo artículos y comprando.

- Lo idóneo es tener una marca propia para la tienda en línea y utilizarla en el dominio. 
- Siempre administrar y monitorear cómo se van manejando los productos en tu tienda.

- Tener temas adicionales, así como diseños originales y utilizar extensiones funcionales.

- No importa qué giro comercial tenga tu negocio en línea, siempre debes poner un soporte para ayuda y un contacto.

Adicionalmente, dentro de las plataformas más usadas se encuentran:

- Palbin.

- Shopify.

- Magento.

- Woocommerce.

- Prestashop.

Ahora bien, debido a que Prestashop permite descargar la tienda para una instalación local, se selecciona esta para el desarrollo del proyecto de fin de semestre de los estudiantes de sistemas de información gerencial en las organizaciones y de comercio y negociaciones virtuales. 


\section{Objetivos y materiales}

\section{Objetivos.}

Instalar una tienda electrónica local para su entrega como proyecto de fin de semestre ajustándola a la matriz de valoración de la profesora.

Materiales.

- Equipo de cómputo.

- Versión reciente de prestashop 1.7.4.2.

- Version de XAMPP para Windows 7.2.7. 


\section{Descripción de actividades y procedimientos de la práctica}

Prestashop es la tienda electrónica que se ajustará siguiendo la matriz de valoración de la profesora. Sin embargo, es importante mencionar qué es XAMPP y cuál es su función en la práctica de la instalación de la tienda electrónica.

\section{XAMPP.}

Es un paquete de software libre que consiste, principalmente, en el sistema de gestión de bases de datos MySQL, el servidor web Apache y los intérpretes para lenguajes de script PHP y Perl. El nombre es en realidad un acrónimo: X (para cualquiera de los diferentes sistemas operativos), Apache, MariaDB/MySQL, PHP, Perl. A partir de la versión 5.6.15, XAMPP cambió la base de datos MySQL por MariaDB, un fork de MySQL con licencia GPL. El programa se distribuye con la licencia GNU y actúa como un servidor web libre, fácil de usar y capaz de interpretar páginas dinámicas. Hasta la fecha, XAMPP está disponible para Microsoft Windows, GNU/Linux, Solaris y Mac OSX (Wikipedia, 2018).

En conclusión, antes de iniciar con la instalación de la tienda primero instalaremos XAMPP, el cual nos proporcionará el servidor que permitirá la simulación de estar conectado a Internet, por tanto, los estudiantes no necesitarán Internet para realizar su trabajo. Además, proporciona la herramienta de gestión de datos que permitirá la creación de una base de datos, la cual se solicita en la instalación de la tienda Prestashop, ya que allí quedará almacenado todo lo que se realice en la tienda como registro de clientes, proveedores, productos, almacenamiento de imágenes etc. 


\section{Instalación de tienda electrónica}

\section{Instalación del programa XAMPP.}

Descargar la última versión de XAMPP (en este caso para Windows, pero también existe versión para Linux y OSX). ${ }^{2}$

Luego de descargar el software, procederemos a instalarlo como un programa más en nuestro equipo. Esto al hacer clic sobre el archivo descargado.

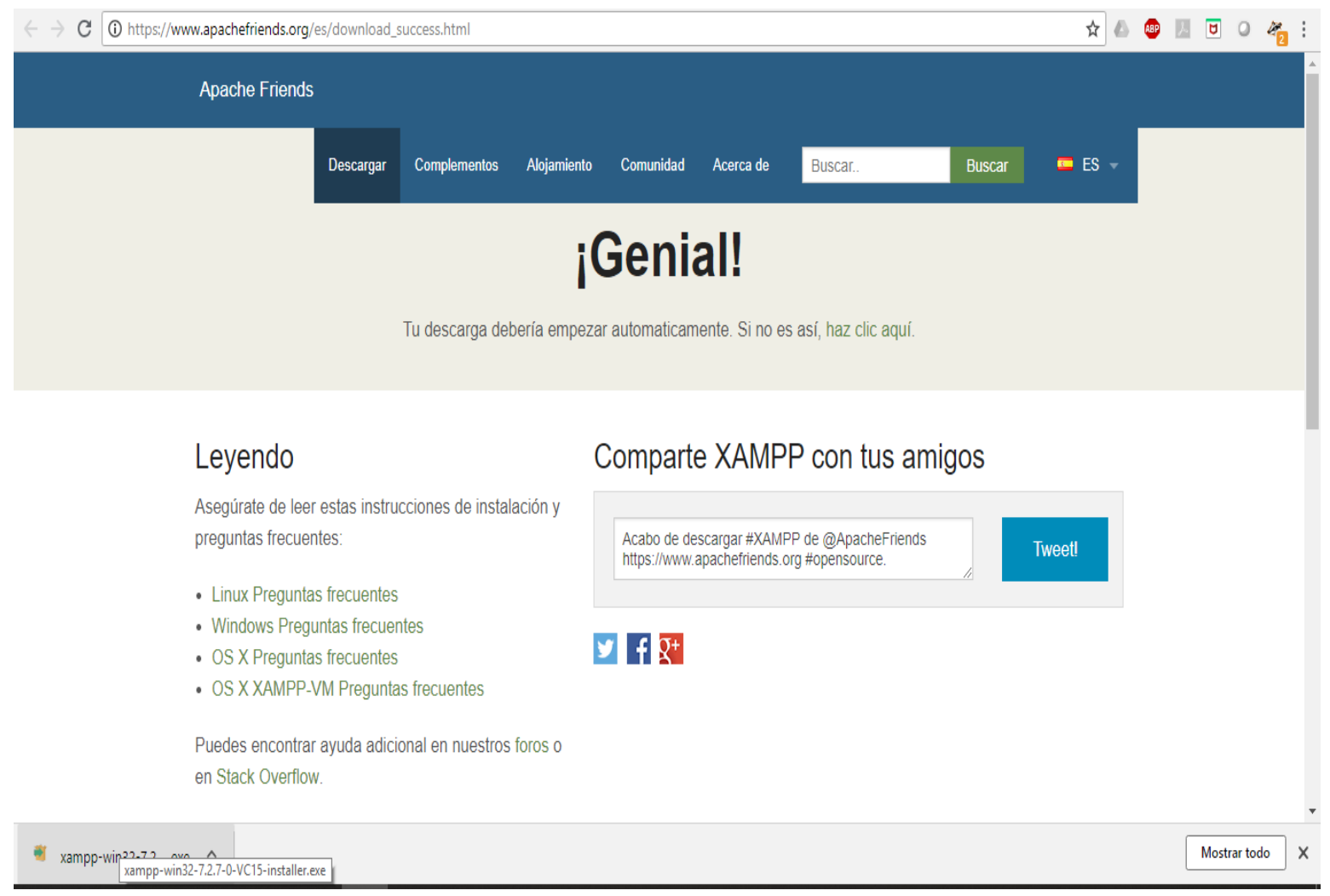

Figura 9. Sitio de descarga XAMPP

Fuente: elaboración propia

${ }^{2}$ Se puede descargar de la URL https://www.apachefriends.org/es/download_success.html 
Si se genera un pantallazo solicitando permiso para la instalación del programa, concedemos el permiso dando clic en el botón "SI".

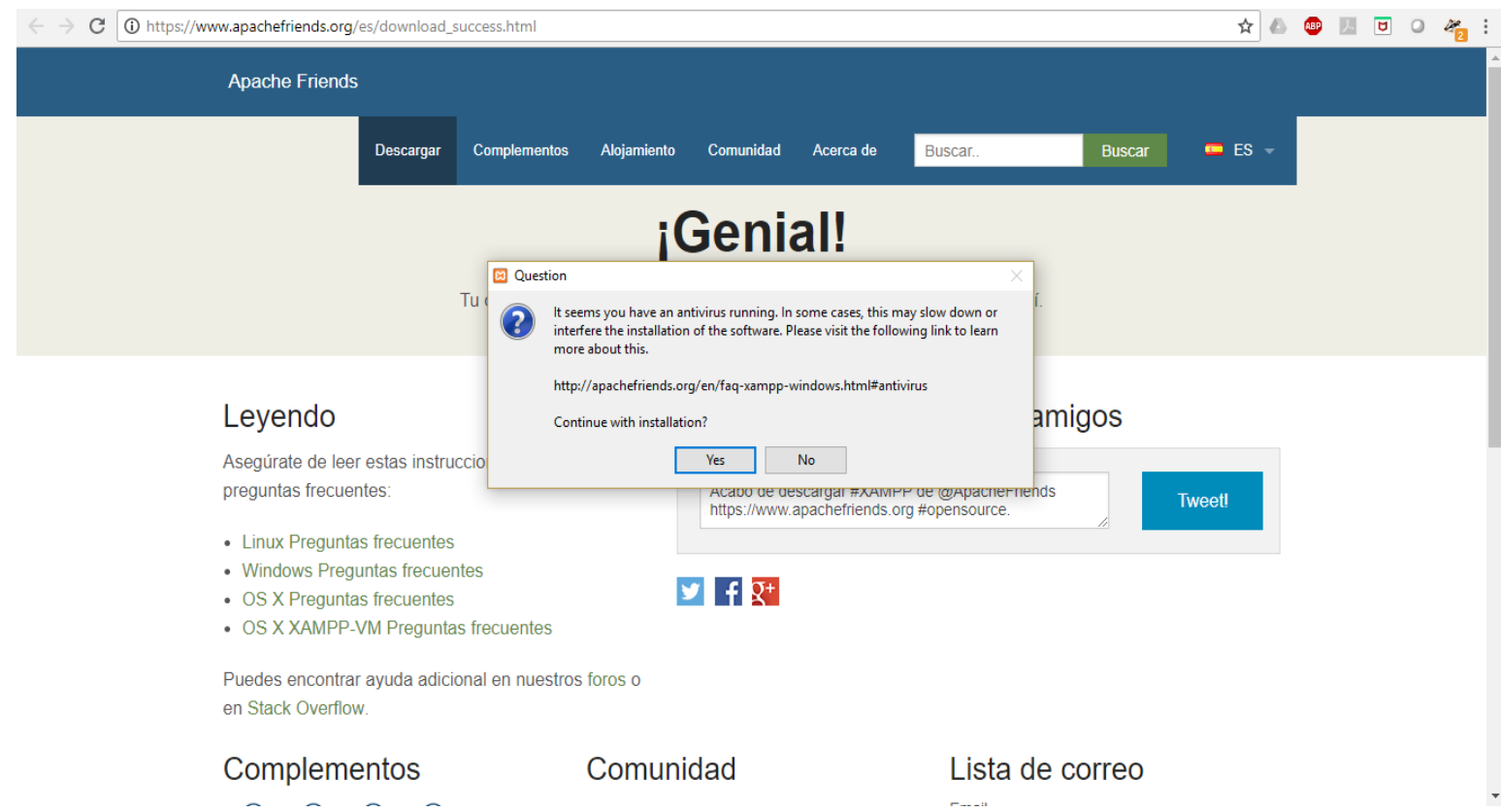

Figura 10. Inicio instalación XAMPP, paso 1

Fuente: elaboración propia

A la pregunta adicional sobre la continuación de la instalación con el antivirus ejecutándose, damos clic en el botón "SI" (en el caso de querer saber más sobre los posibles efectos del antivirus activo al momento de la instalación de XAMPP, entrar al sitio indicado en el mensaje de texto). 
C (i) https://www.apachefriends.org/es/download__success.html

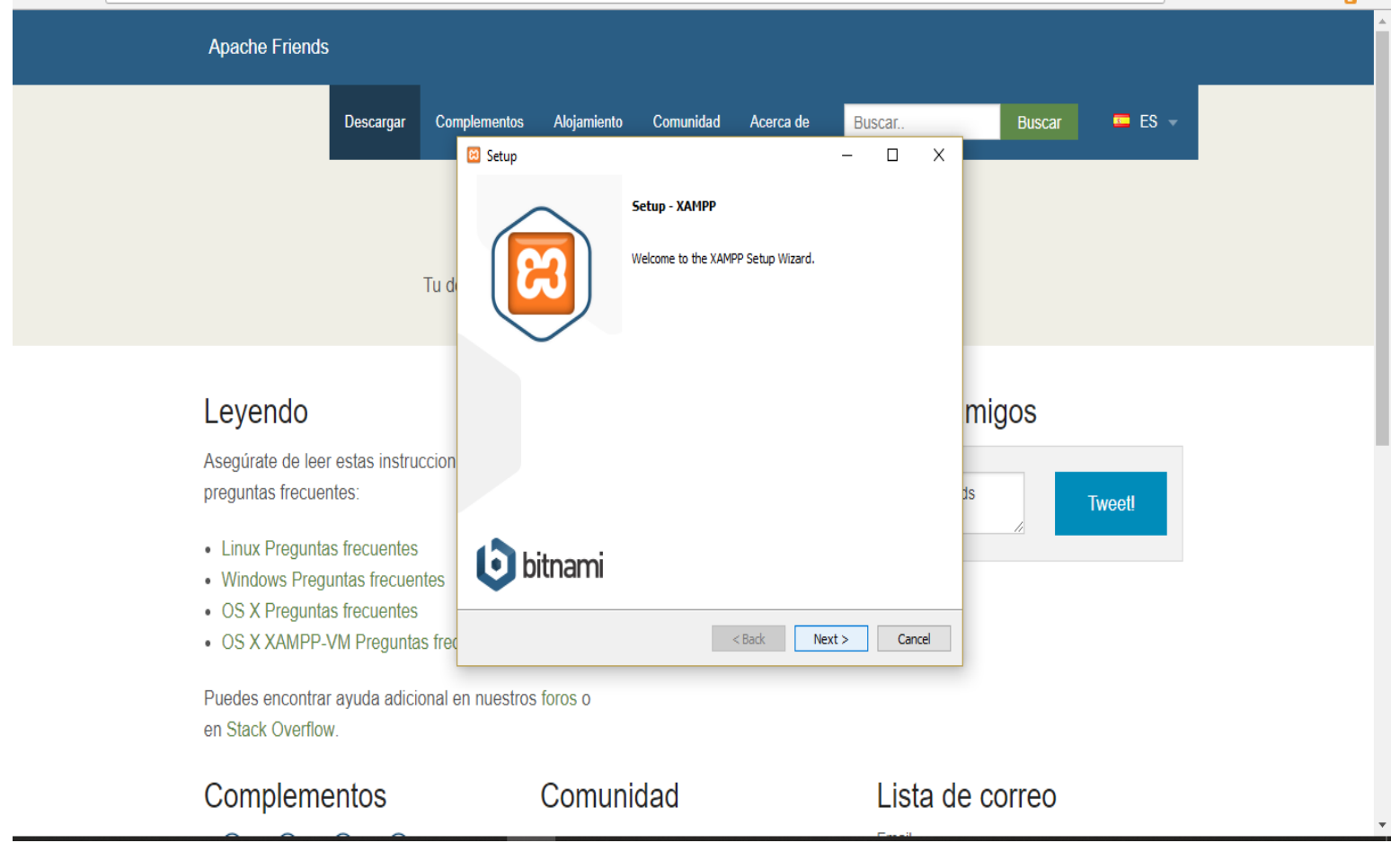

Figura 11. Inicio instalación XAMPP, paso 2

Fuente: elaboración propia

Se inicia la instalación al dar clic en el botón "NEXT".

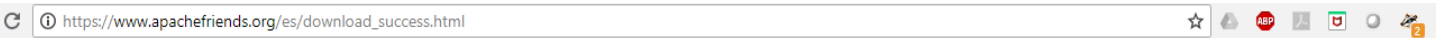

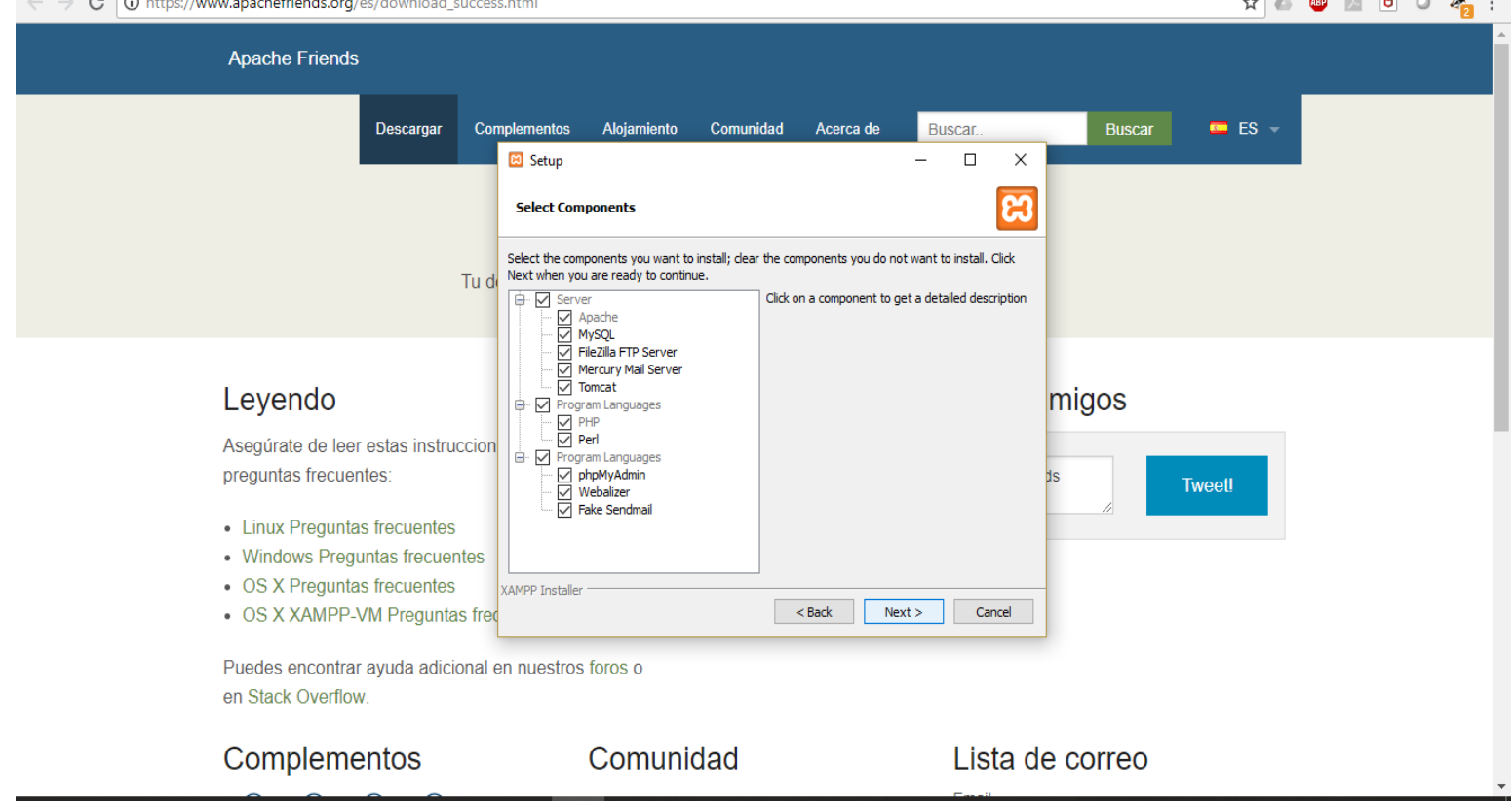

Figura 12. Inicio instalación XAMPP, paso 3

Fuente: elaboración propia 
En el siguiente paso, haga clic en el botón "NEXT".

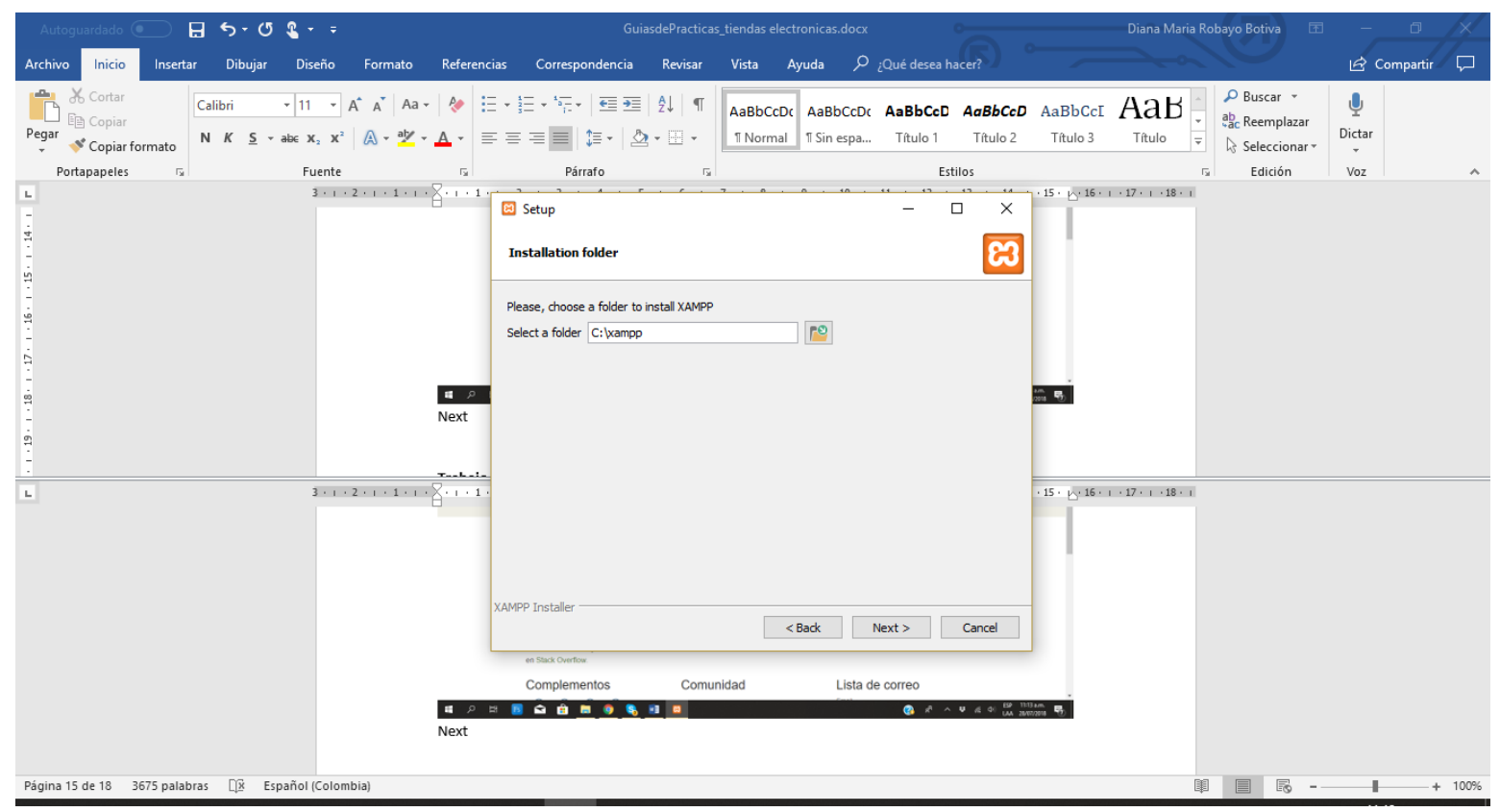

Figura 13. Inicio instalación XAMPP, paso 4

Fuente: elaboración propia

En el siguiente paso, haga clic en el botón "NEXT".

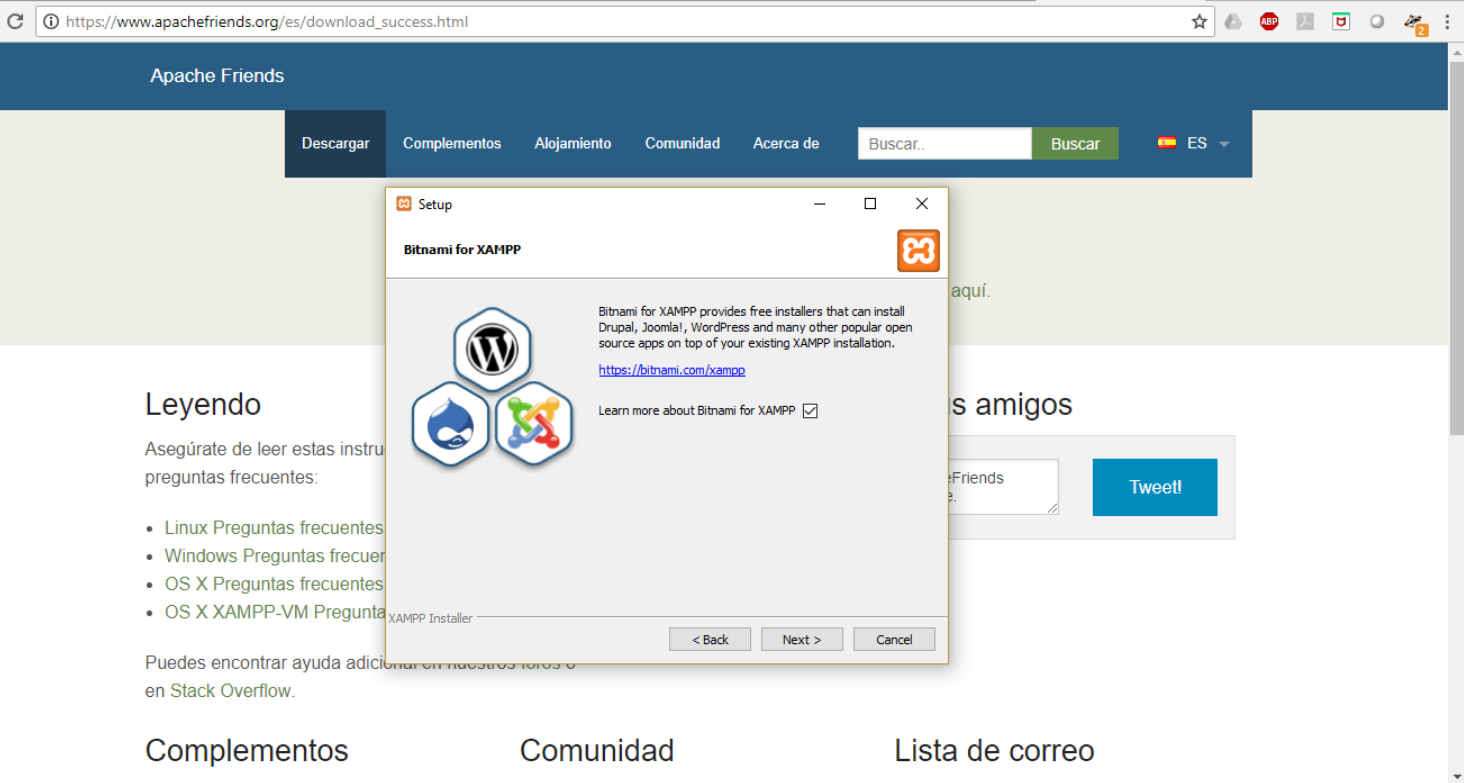

Figura 14. Inicio instalación XAMPP, paso 5

Fuente: elaboración propia 
En el siguiente paso, haga clic en el botón "NEXT".

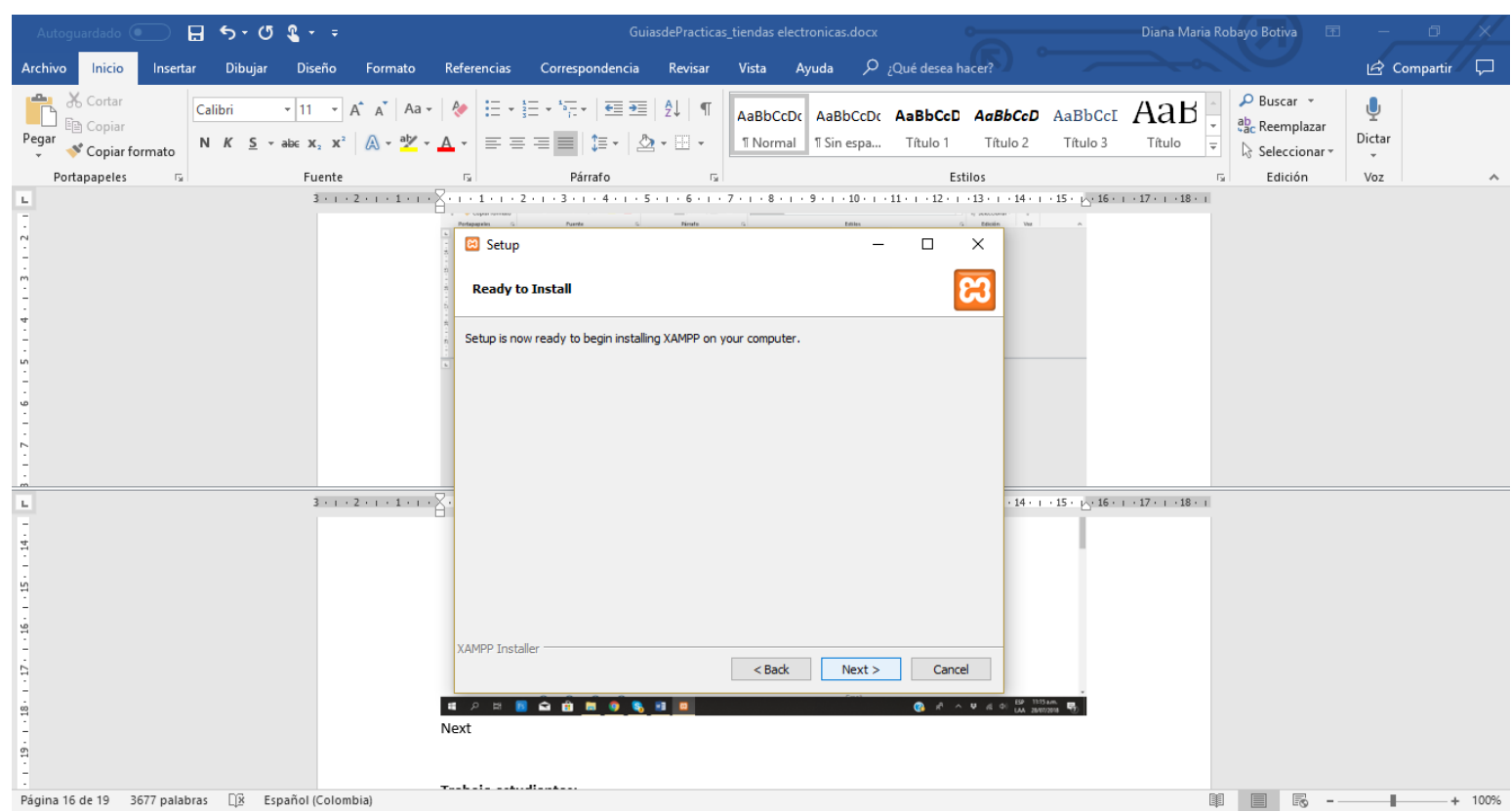

Figura 15. Inicio instalación XAMPP, paso 6

Fuente: elaboración propia

En el siguiente paso, haga clic en el botón "NEXT" y esperamos que finalice la instalación.

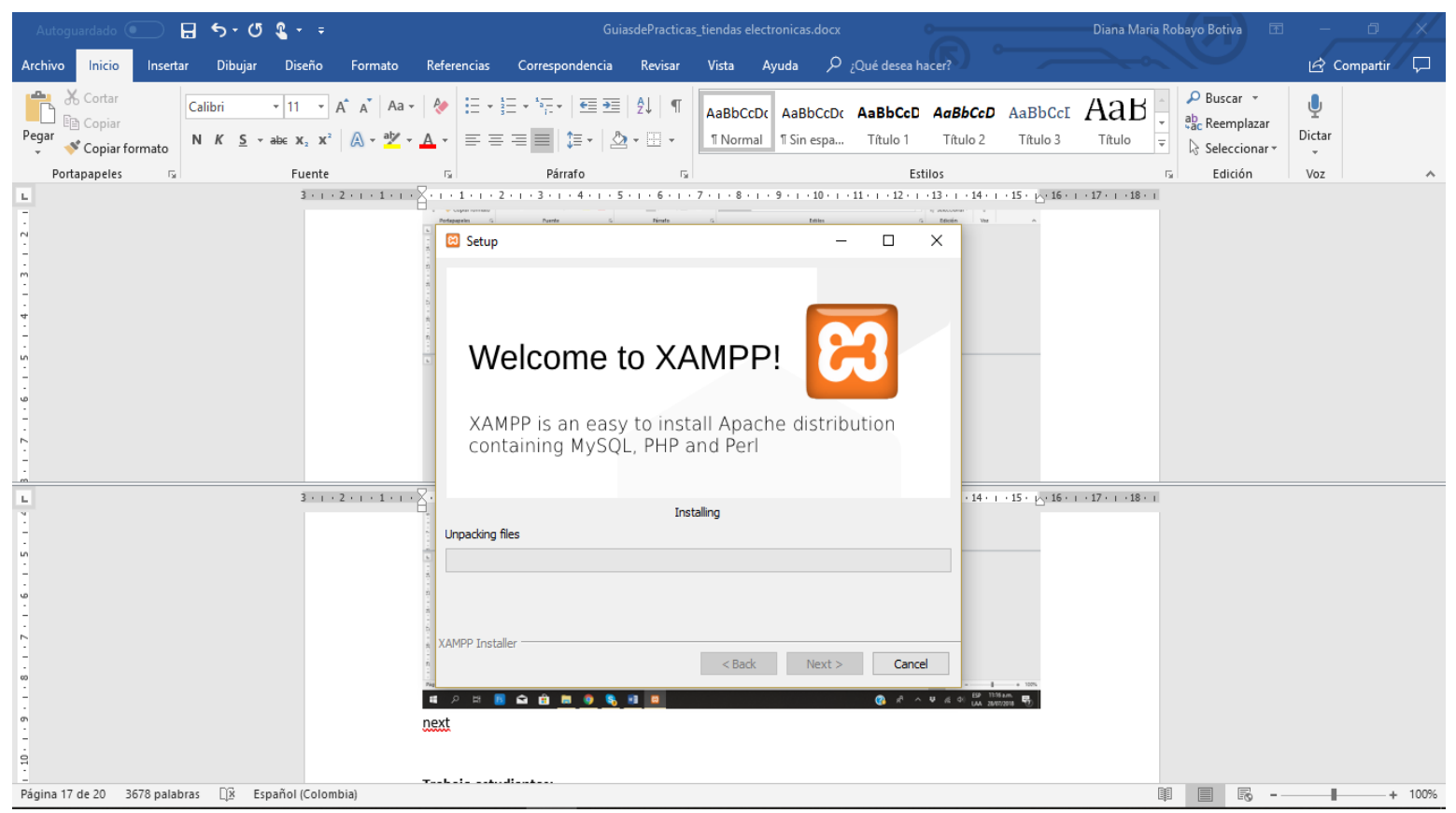

Figura 16. Inicio instalación XAMPP, paso 7

Fuente: elaboración propia 
Finalizada la instalación, damos clic en la opción "Finish".

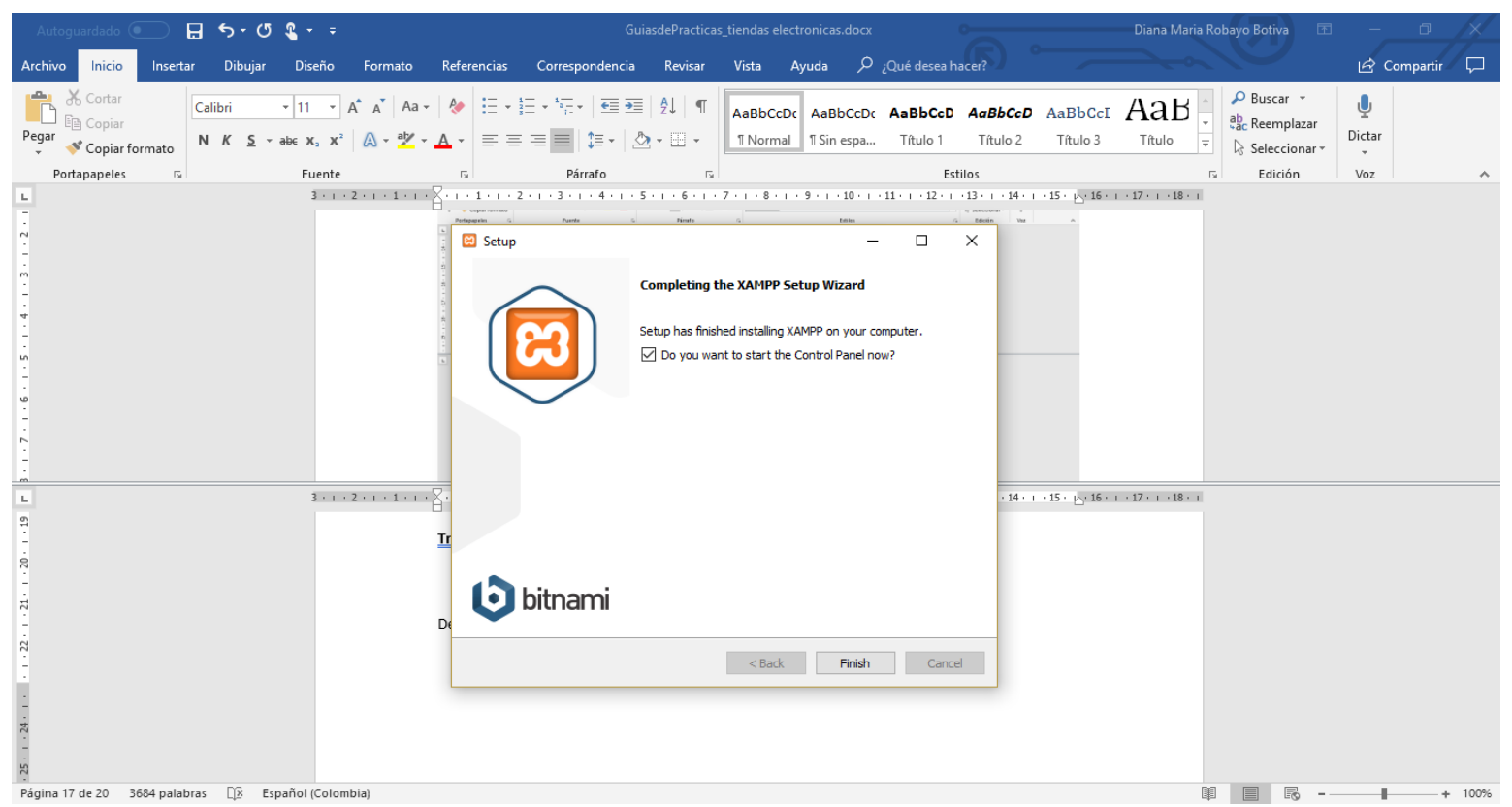

Figura 17. Inicio instalación XAMPP, paso 8

Fuente: elaboración propia

Luego, aparece el siguiente cajón de texto para seleccionar el idioma; dejamos el idioma por defecto (inglés).

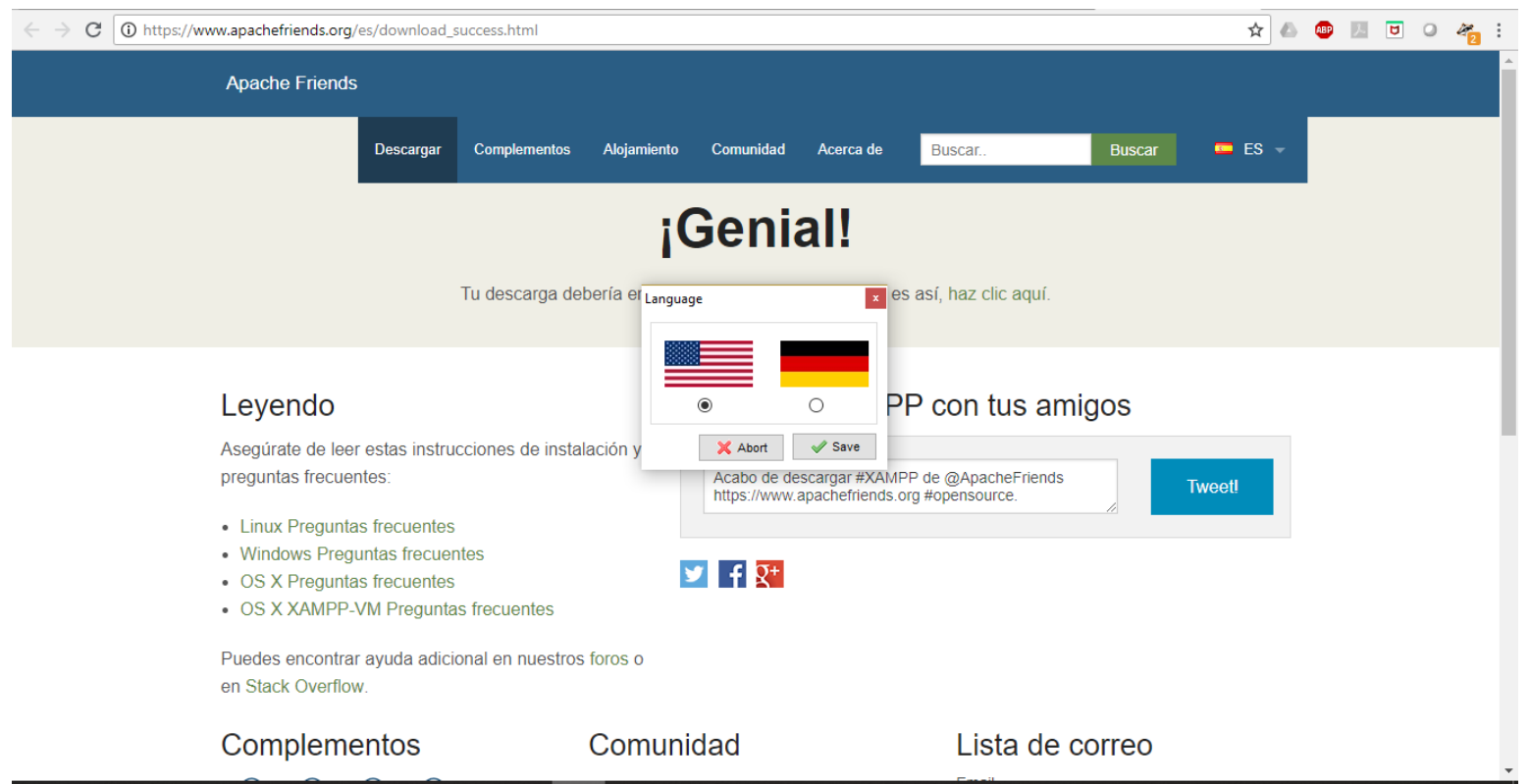

Figura 18. Inicio instalación XAMPP, paso 9

Fuente: elaboración propia 
Se da clic en "Save" ("guardar") e inmediatamente en la parte inferior derecha aparece un icono de XAMPP.

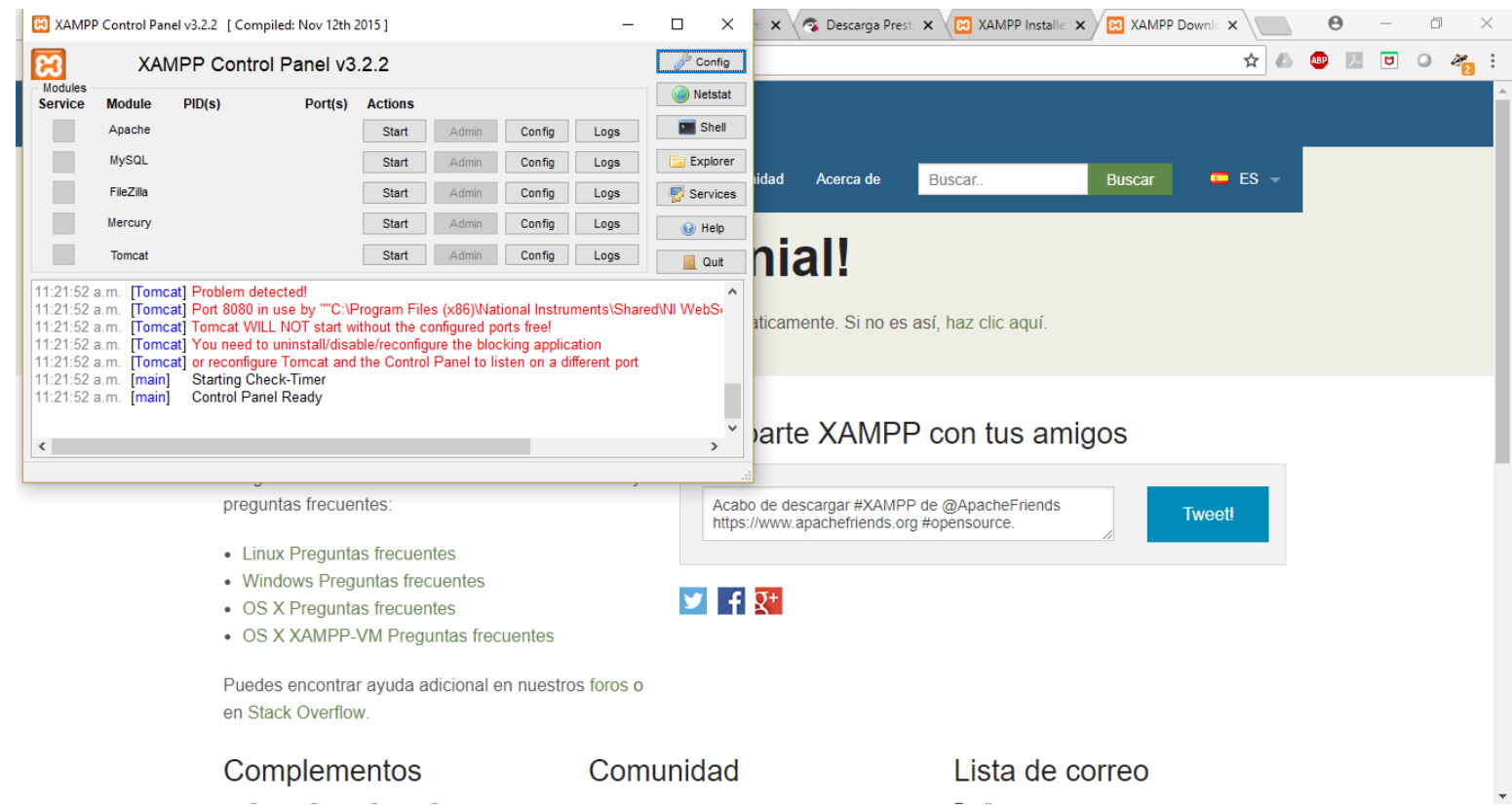

Figura 19. Vista icono de XAMPP en la barra de herramientas de Windows Fuente: elaboración propia

Adicional, aparece el panel de control de la figura 20.

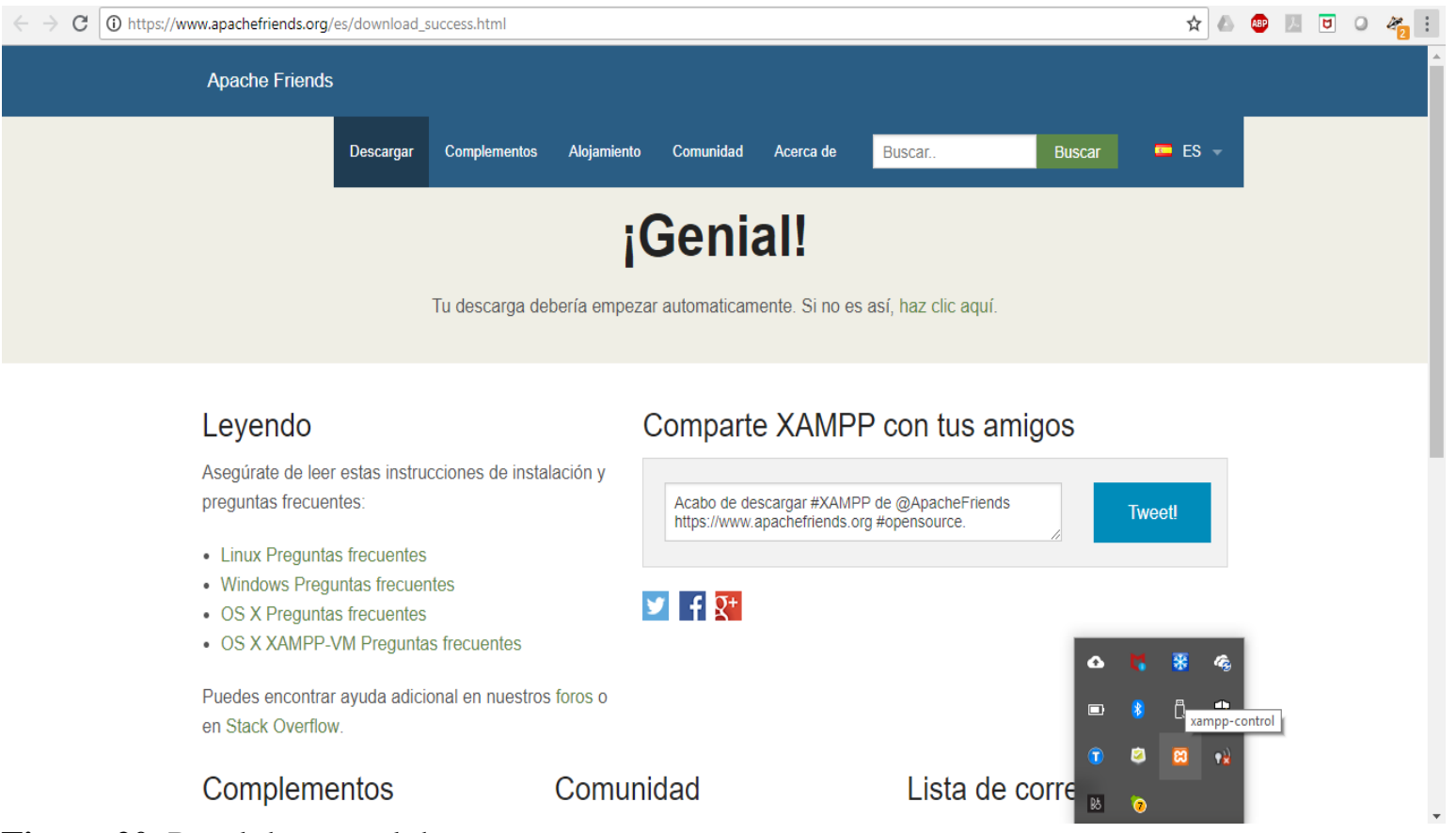

Figura 20. Panel de control de XAMPP

Fuente: elaboración propia 
Luego, se da clic al botón denominado "Start" que activa Apache y MySQL, respectivamente.

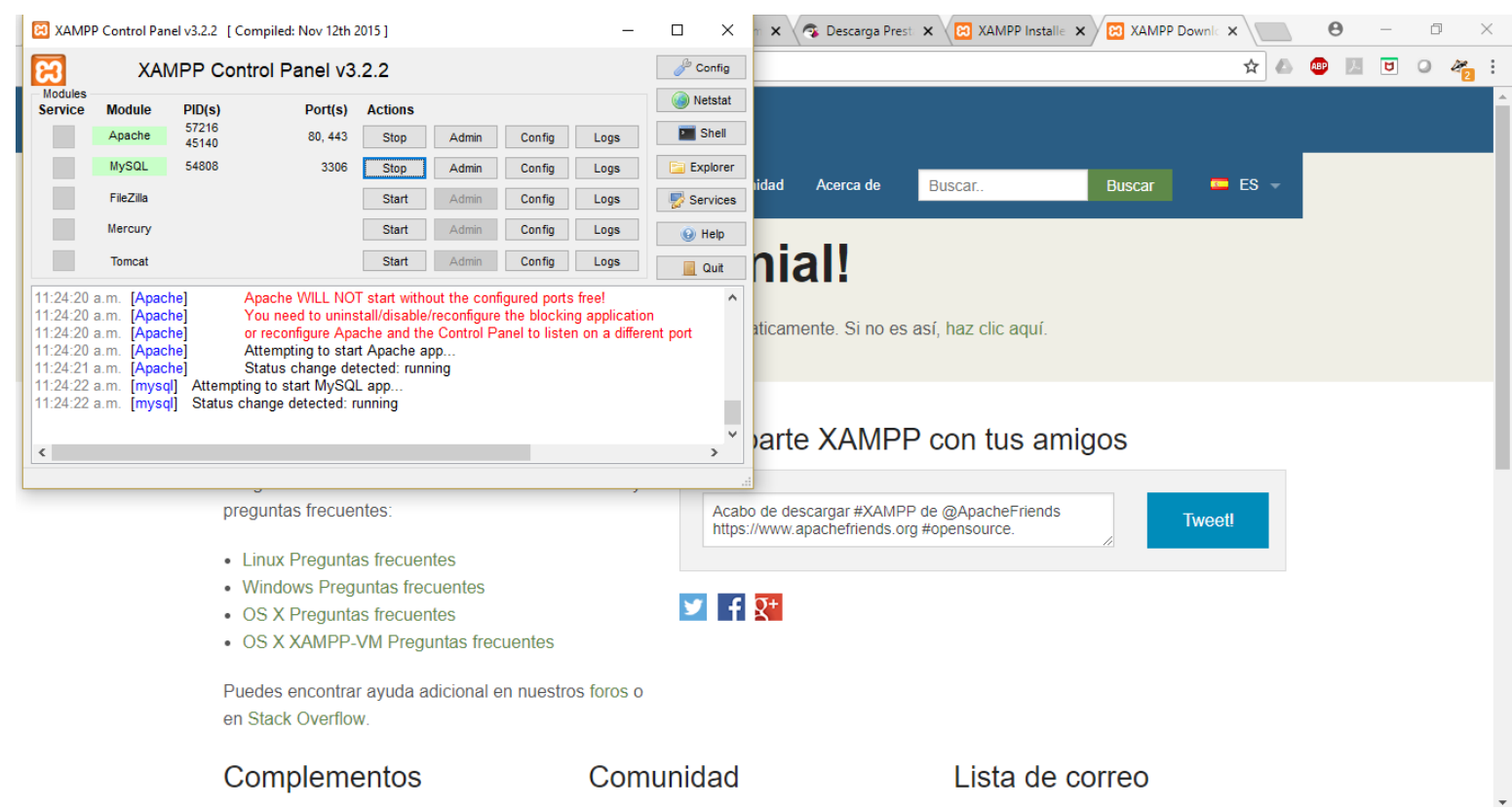

Figura 21. Configuración de XAMPP, paso 1

Fuente: elaboración propia

Al dar clic en el botón "Start" de los servicios de Apache y MySQL, estos últimos deben cambiar a color verde, indicando que se encuentran habilitados.

Luego, para continuar se debe crear una base de datos, por tanto, dar clic en la opción “Admin" de MySQL. 


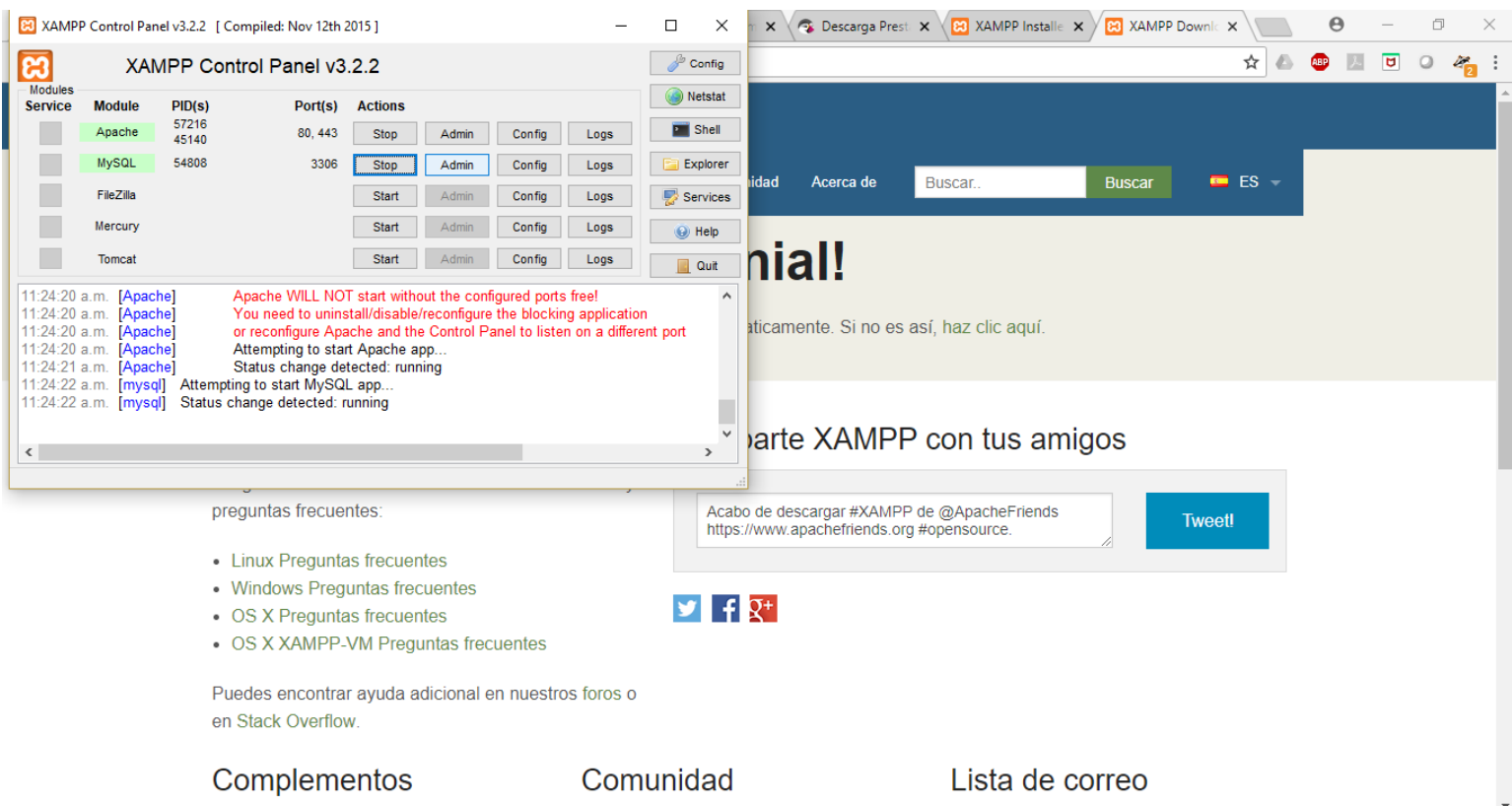

Figura 22. Creación de base de datos, paso 1

Fuente: elaboración propia

Debe entonces abrirse una página web.

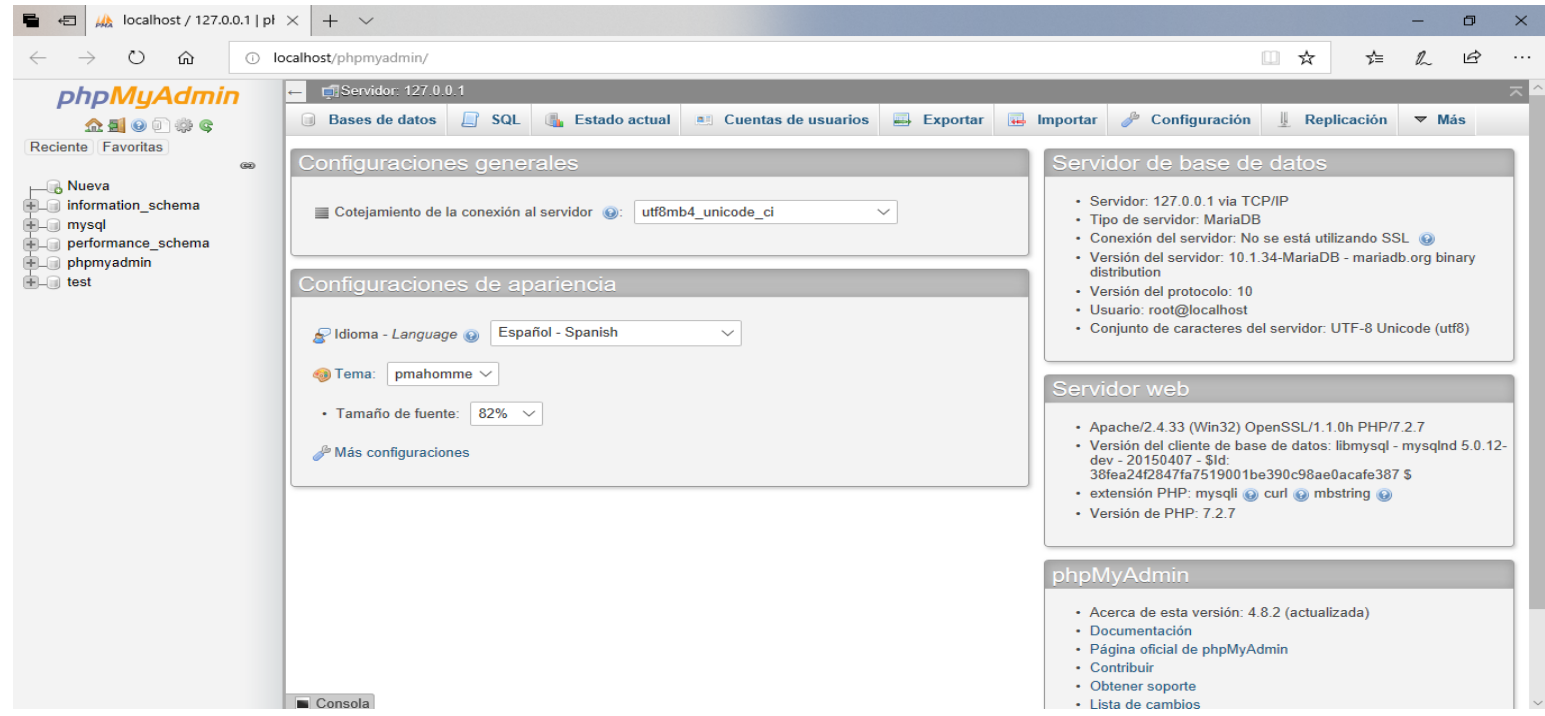

Figura 23. Creación de base de datos, paso 2

Fuente: elaboración propia

Aquí se crea la base de datos antes de continuar con el proceso de instalación de la tienda. Dar clic en la opción superior izquierda denominada "Bases de datos" y debe aparecer la imagen que se muestra en la figura 24. 


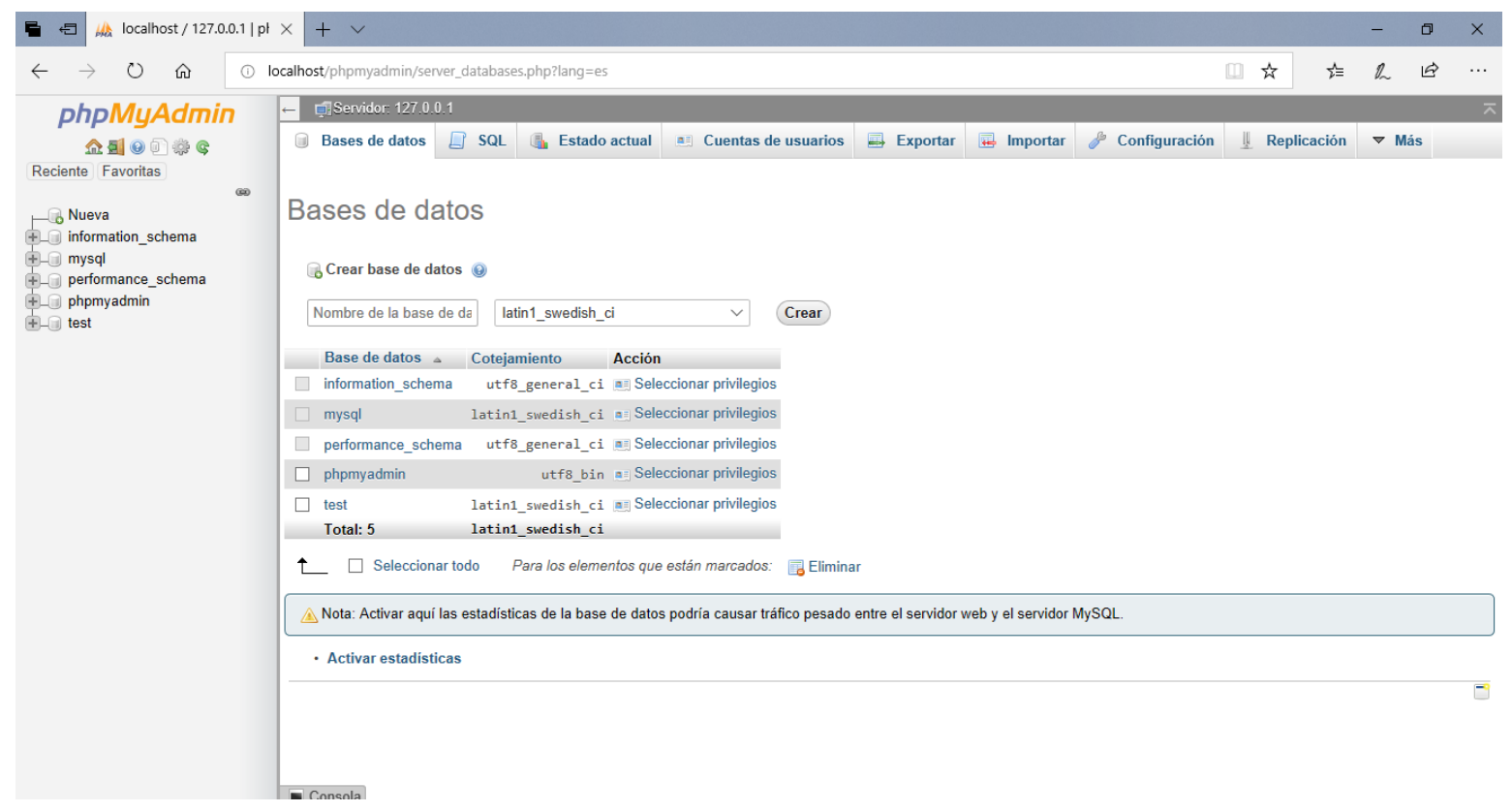

Figura 24. Creación de base de datos, paso 3

Fuente: elaboración propia

En el cajón de texto, debajo del texto "Crear base de datos", se coloca un nombre, en este caso, se colocará "comercio" y se da clic en "Crear".

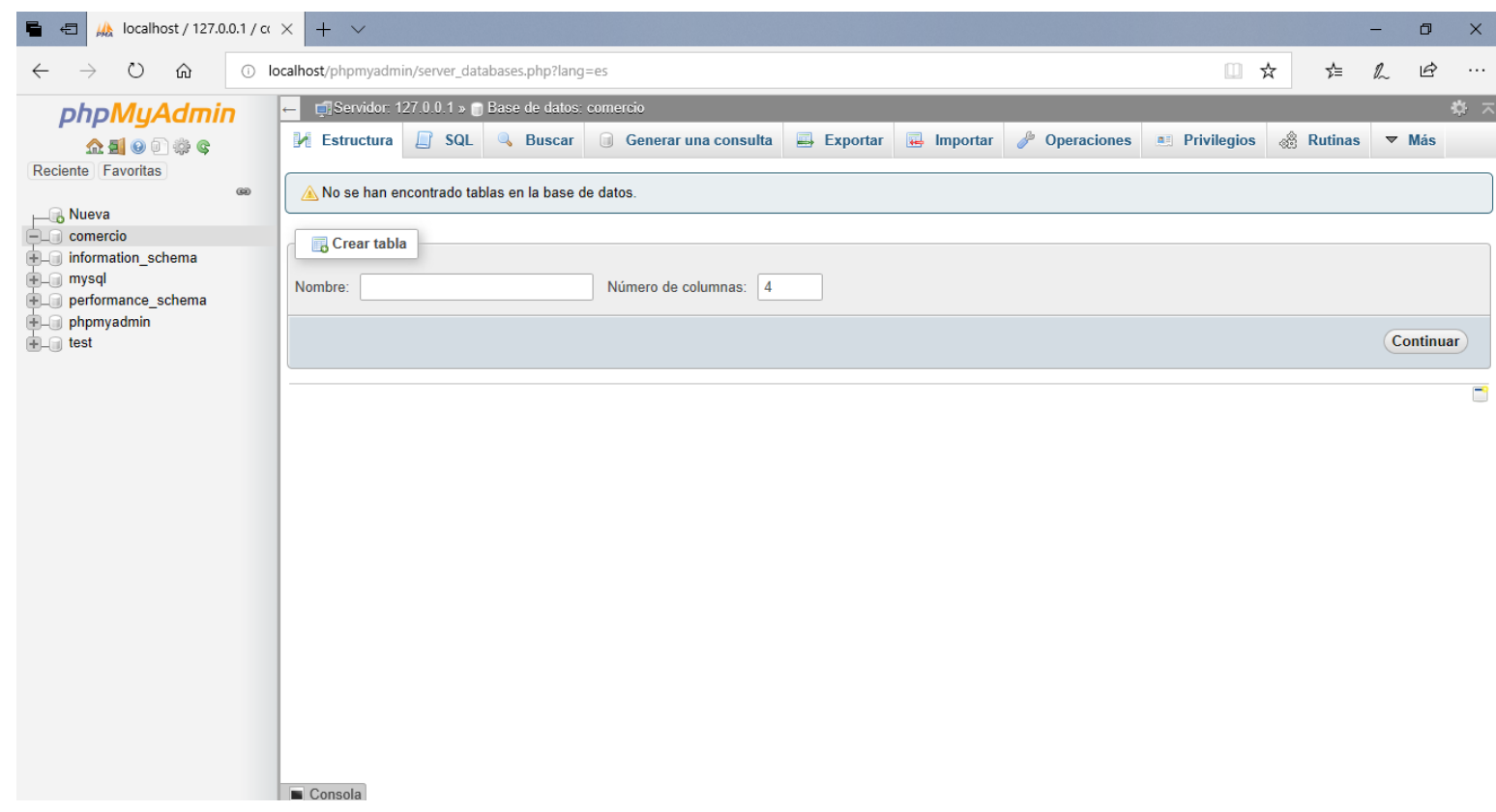

Figura 25. Creación de base de datos, paso 4

Fuente: elaboración propia 
Se puede evidenciar que en la parte izquierda aparece la base de datos creada

Cerrar Explorer y minimizar el panel de control de XAMPP, a fin de proceder a descargar la tienda electrónica para su posterior instalación.

\section{Instalación de tienda Prestashop}

Primero, en la URL https://www.prestashop.com/es/descarga, se realiza un registro antes de descargar. Se aceptan las condiciones y se da clic en "Descarga".

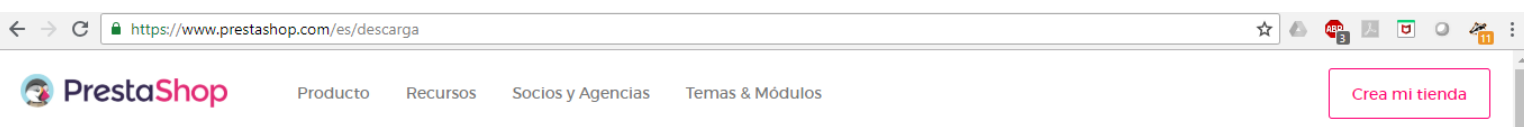

\section{Descarga PrestaShop y crea tu tienda online}

Descarga gratis el software de código abierto PrestaShop y disfruta de su nueva versión 1.7.4.2.

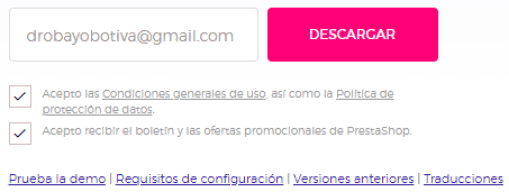

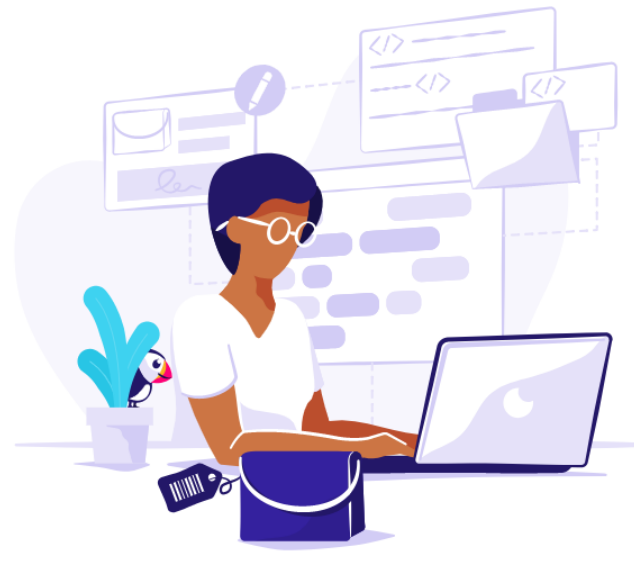

Figura 26. Sitio de descarga de Prestashop Fuente: elaboración propia

Al instante se inicia la descarga de un archivo .rar que queda en la carpeta descargas, de otro lado se abre la página que se muestra en la figura 27. 


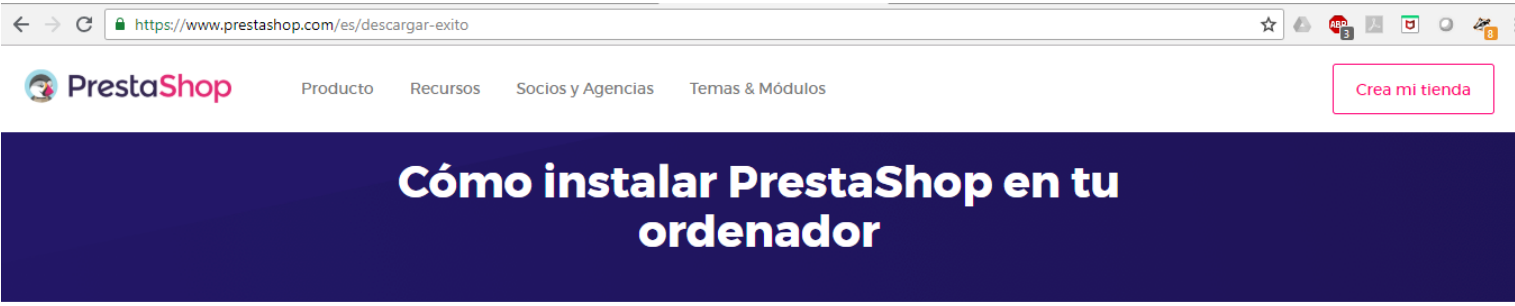

\section{¡Tu tienda instalada en lo que tardas en tomarte un café!}

Figura 27. Recomendaciones para instalar Prestashop Fuente. elaboración propia

Ir a la carpeta descargas y buscar el último archivo descargado que es .rar.

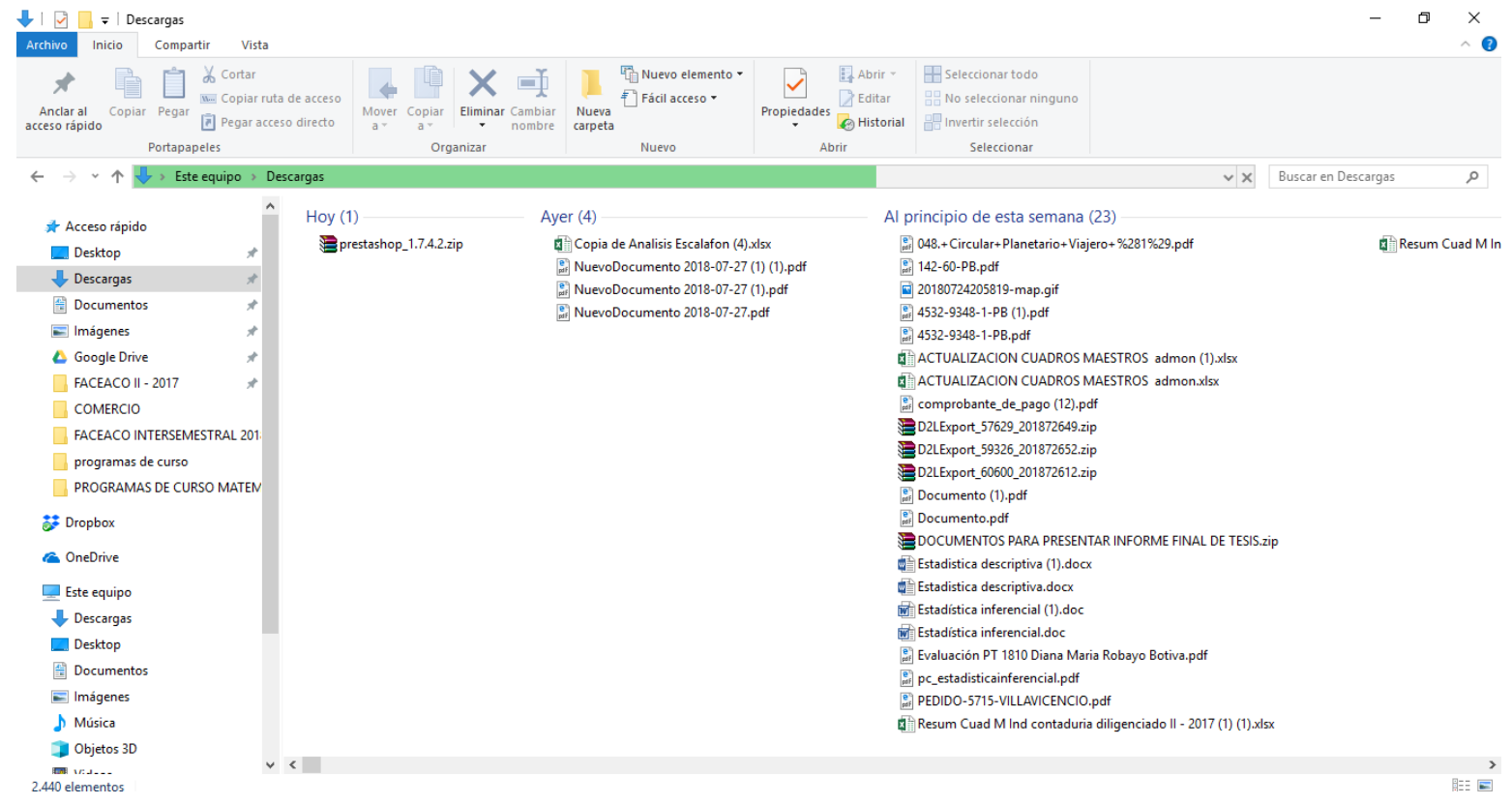

Figura 28. Sitio donde se encuentra descargado Prestashop en el equipo Fuente: elaboración propia

Se descomprime al dar clic derecho y se selecciona la opción "Extraer fichero". 


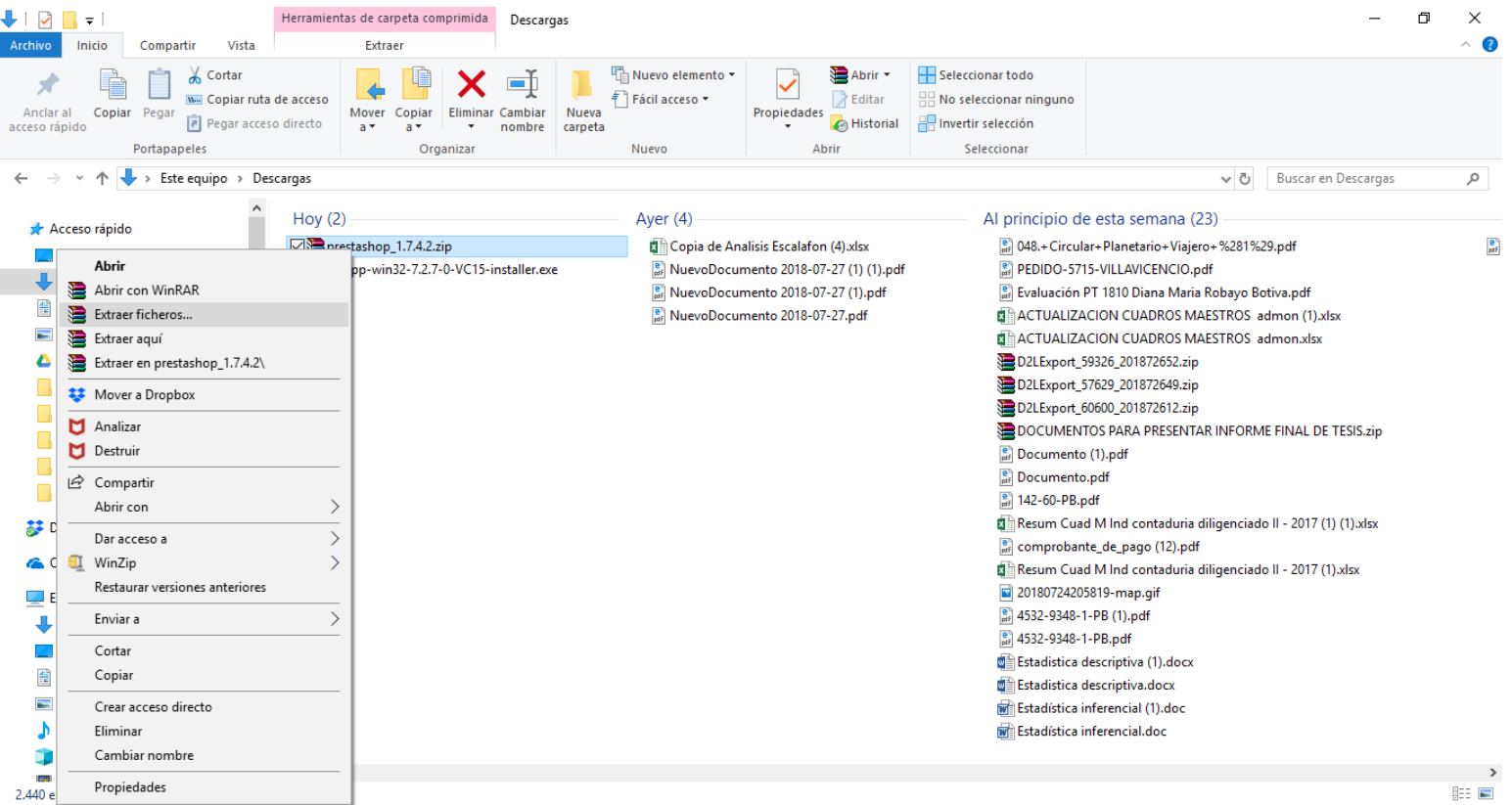

Figura 29. Inicio de descompresión de archivo en el equipo

Fuente: elaboración propia

Debe aparecer lo que se observa en la figura 30.

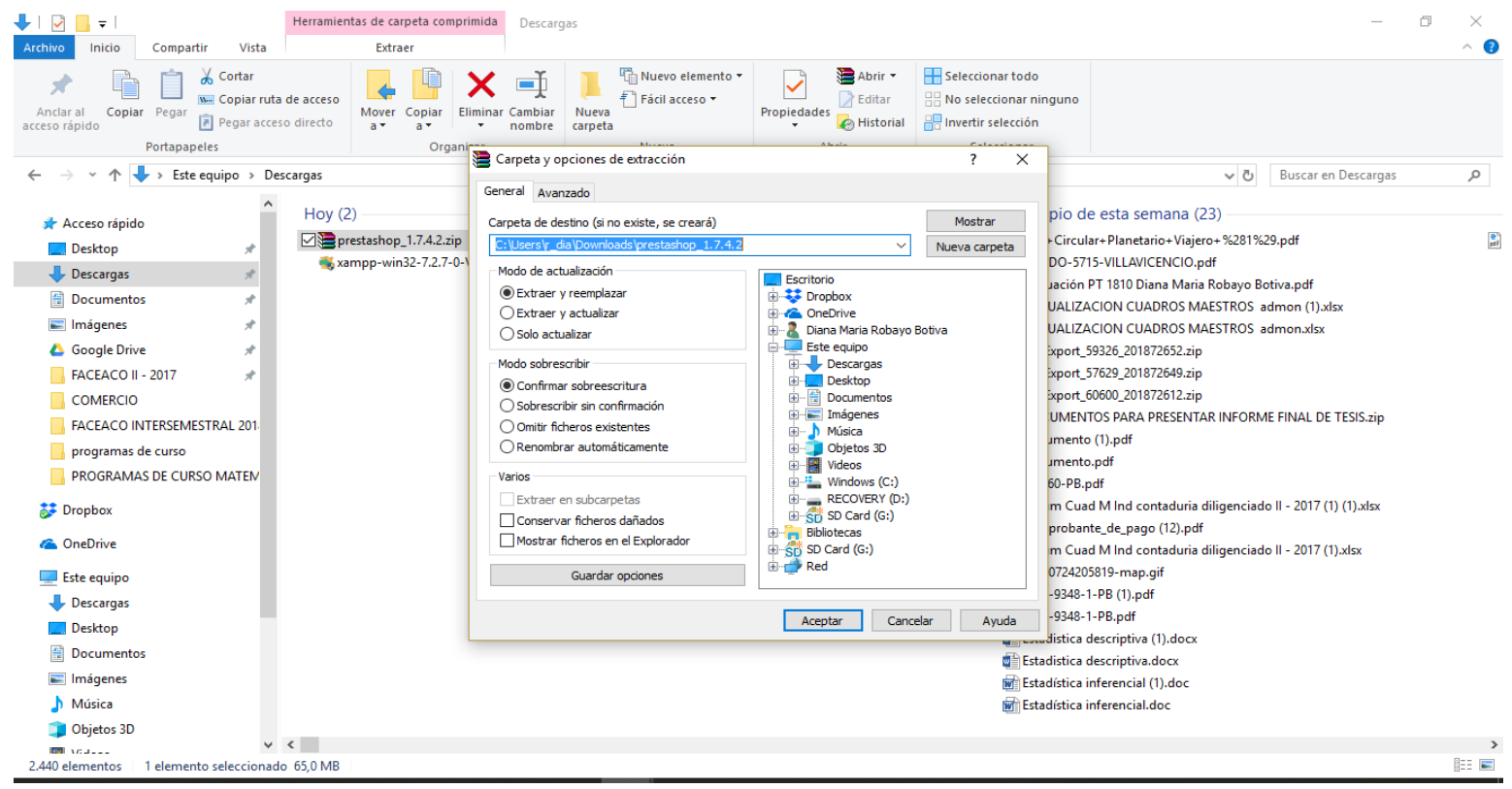

Figura 30. Búsqueda de ruta para la descompresión del archivo de instalación Fuente: elaboración propia 
Se selecciona la siguiente ruta: C/XAMPP/htdocs; en esta carpeta directamente se descomprime, al dar clic en la opción "Aceptar".

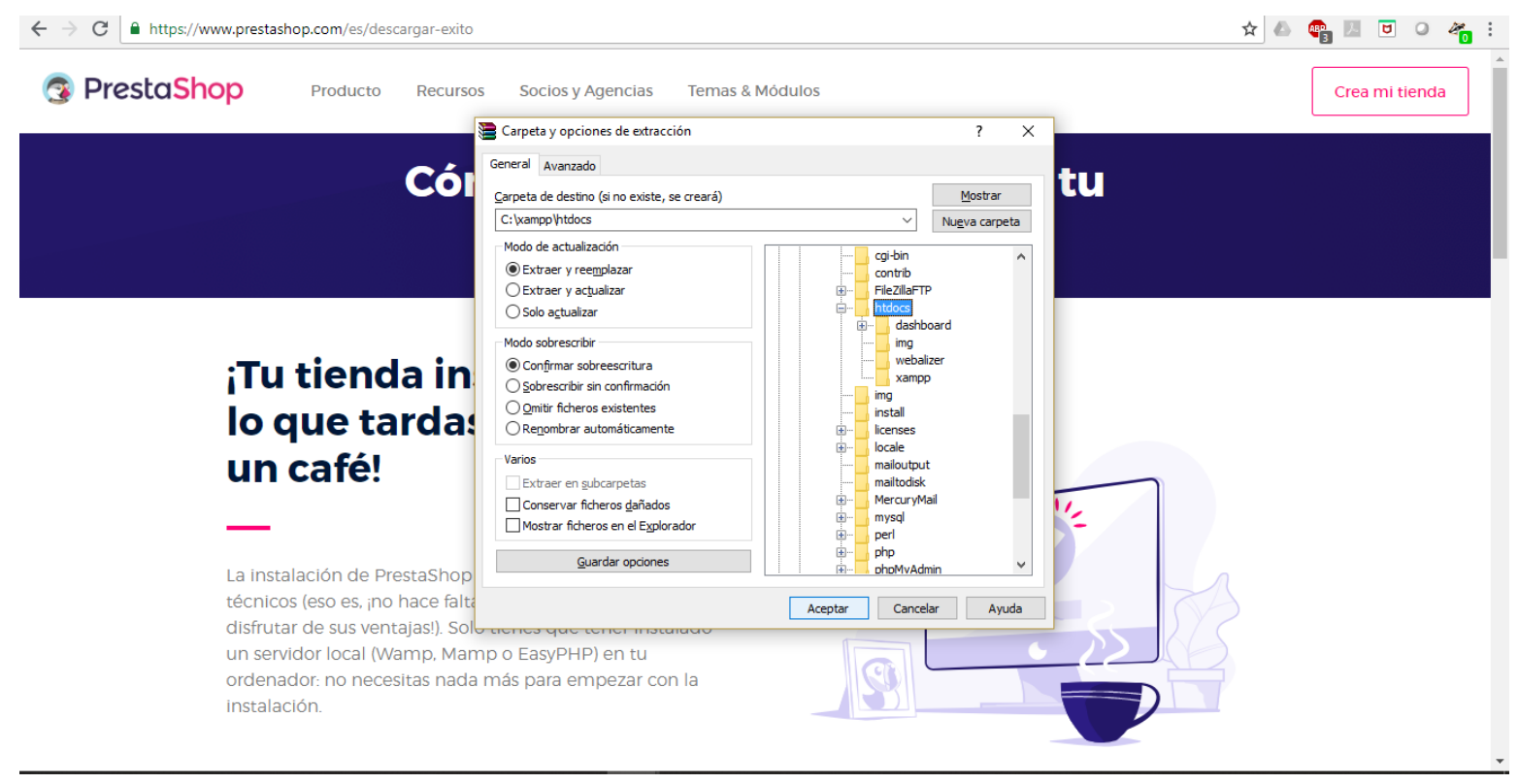

Figura 31. Ruta para la descompresión del archivo Fuente: elaboración propia

Luego de descomprimir, abrir Chrome, no necesariamente Explorer, y digitar lo siguiente: 127.0.0.1.

Se inicia así la instalación de Prestashop. 


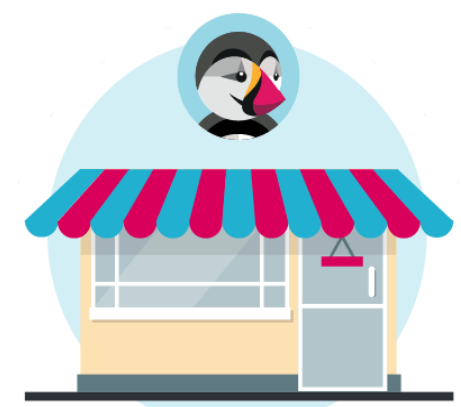

Figura 32. Inicio de instalación de la tienda electrónica Fuente: elaboración propia

Debe esperar para seguir con los pasos.

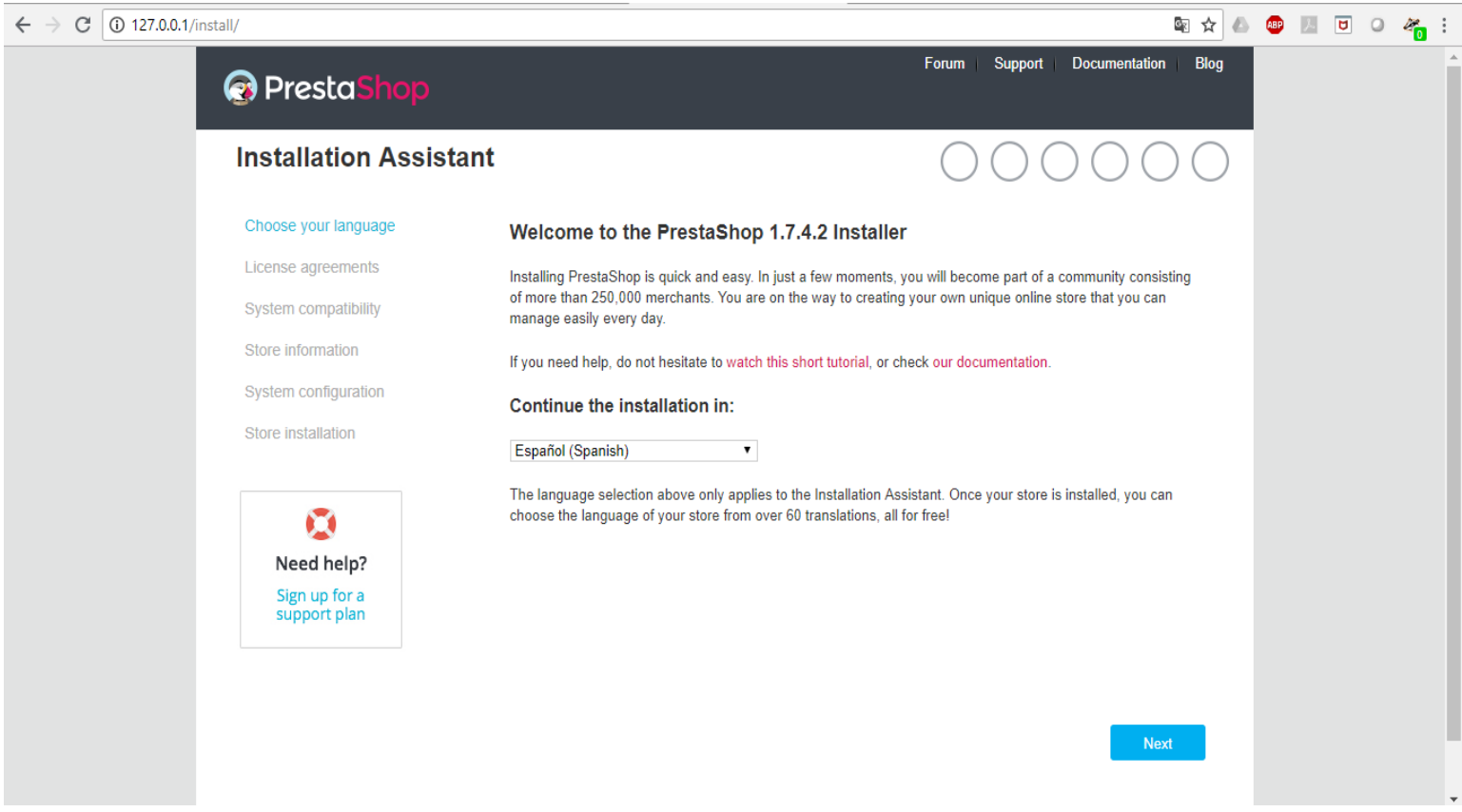

Figura 33. Instalación de la tienda, paso 1

Fuente: elaboración propia

Dejar el idioma de español y dar clic en el botón "NEXT". 


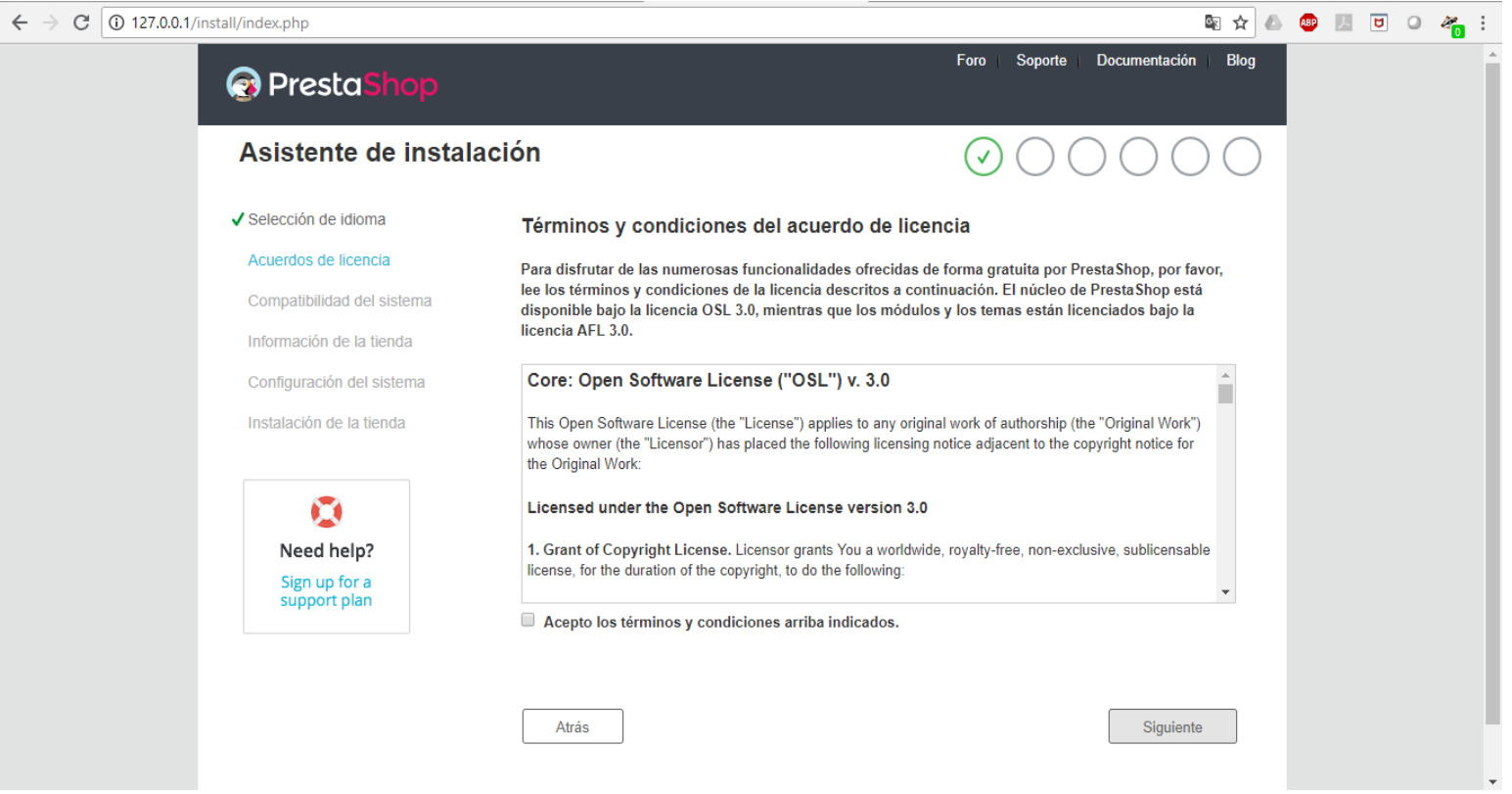

Figura 34. Instalación de la tienda, paso 2

Fuente: elaboración propia

Se aceptan las condiciones de la tienda y se hace clic en el botón "Siguiente".

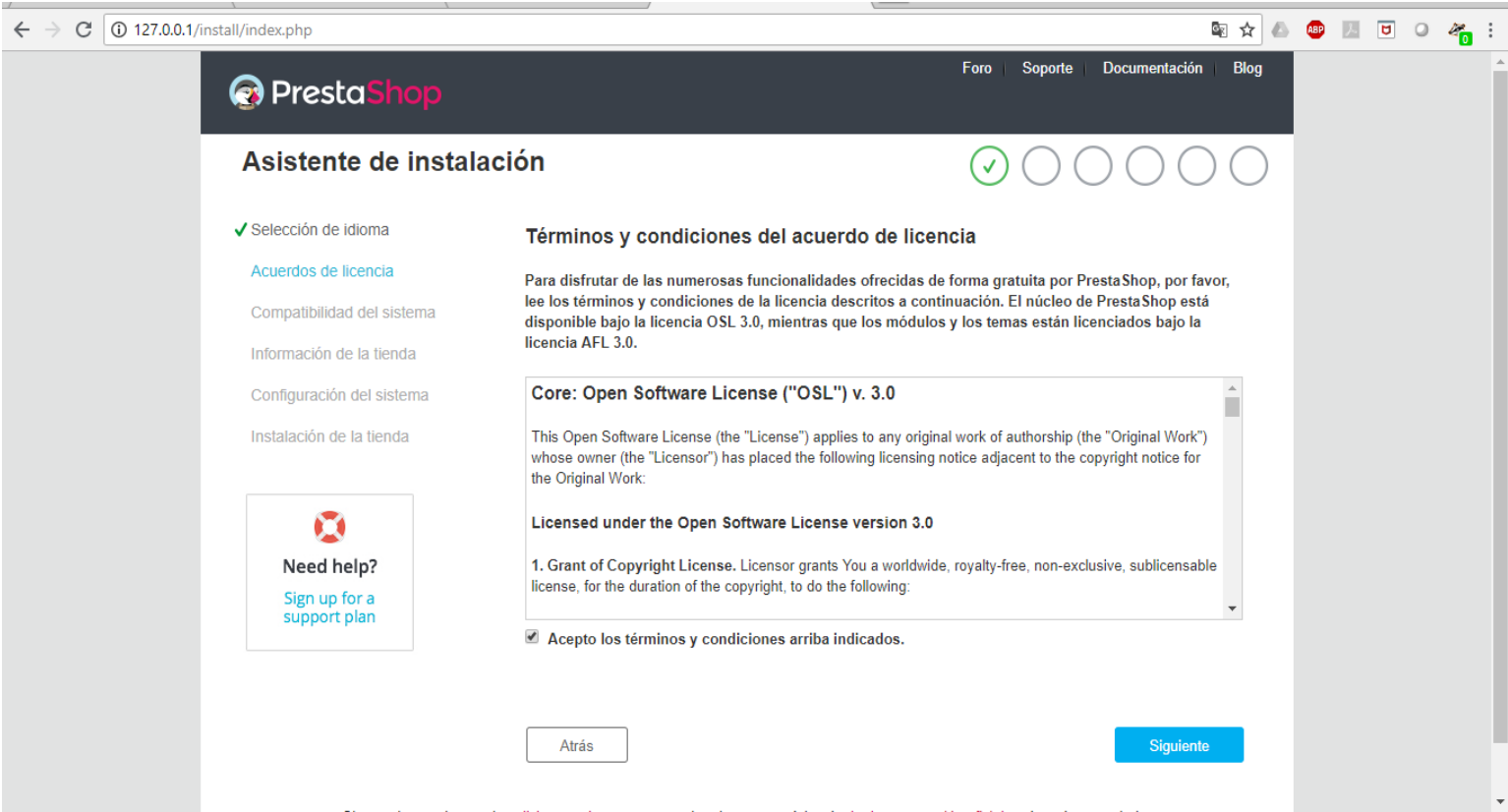

Figura 35. Instalación de la tienda, paso 3

Fuente: elaboración propia 


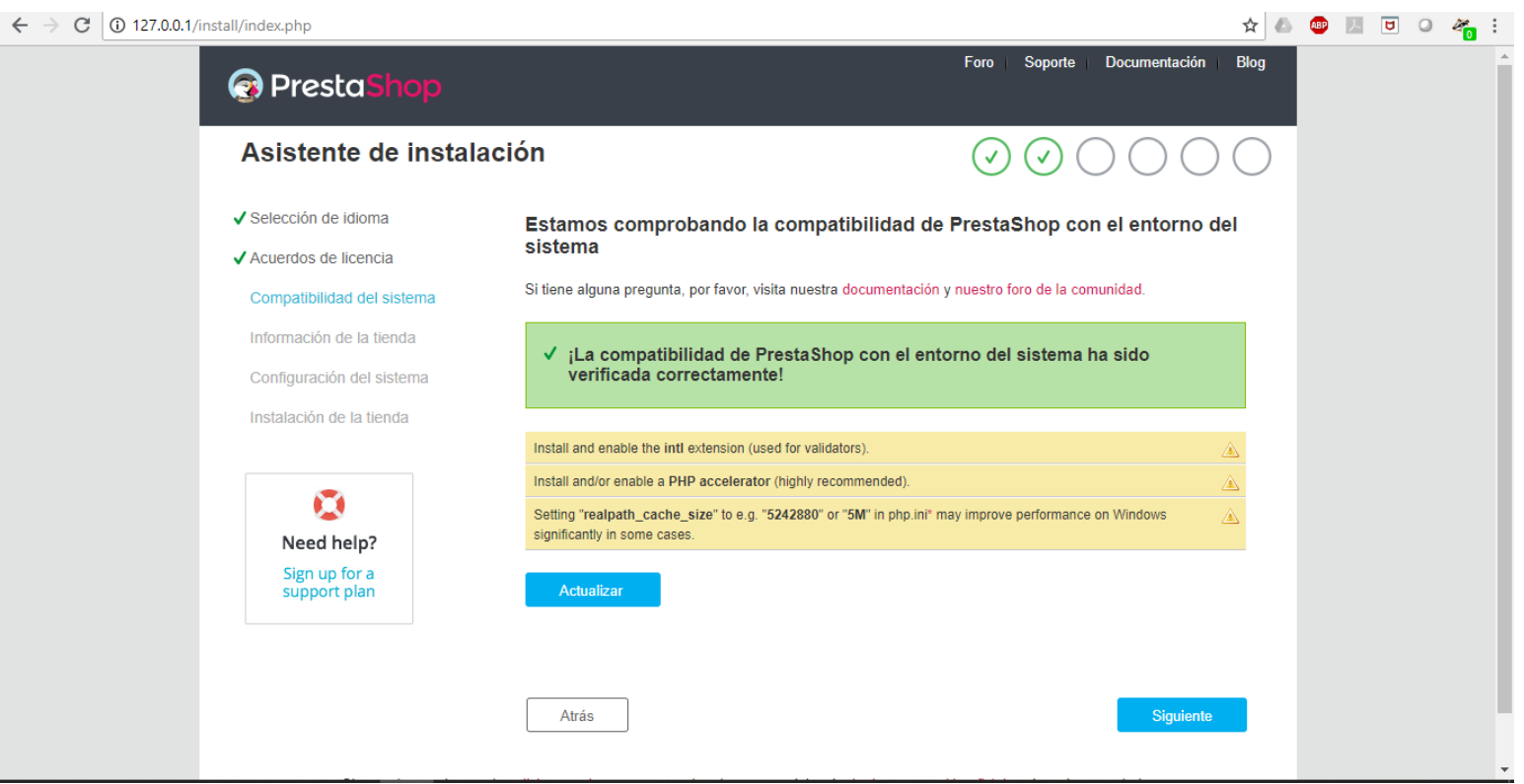

Figura 36. Instalación de la tienda, paso 4

Fuente: elaboración propia

Se corrigen los recuadros amarillos y se modifican el archivo de texto php.ini, y aparece lo que se observa en la figura 37.

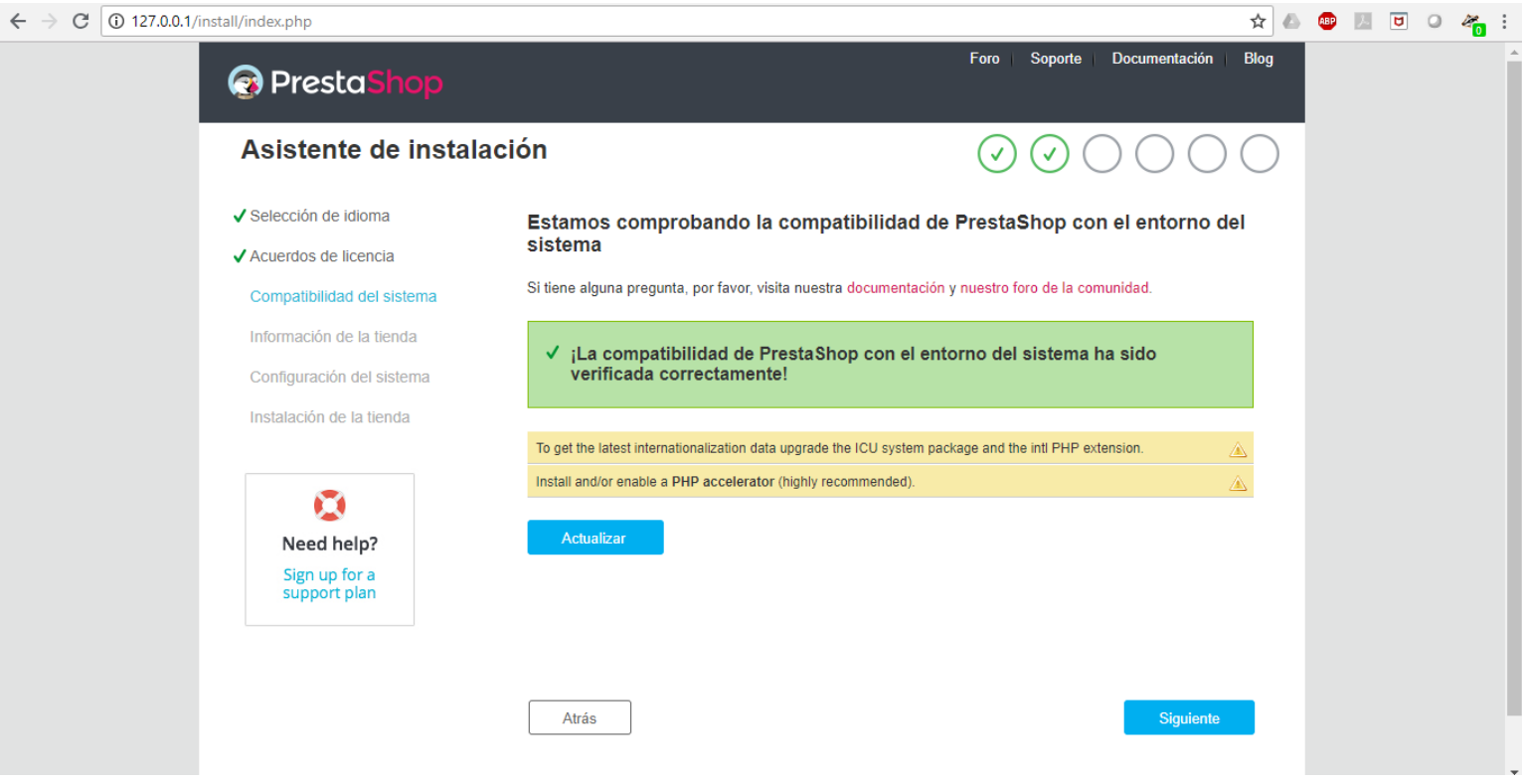

Figura 37. Instalación de la tienda, paso 5

Fuente: elaboración propia 
Dar clic en el botón "Siguiente" y digitar datos de la información de la tienda.

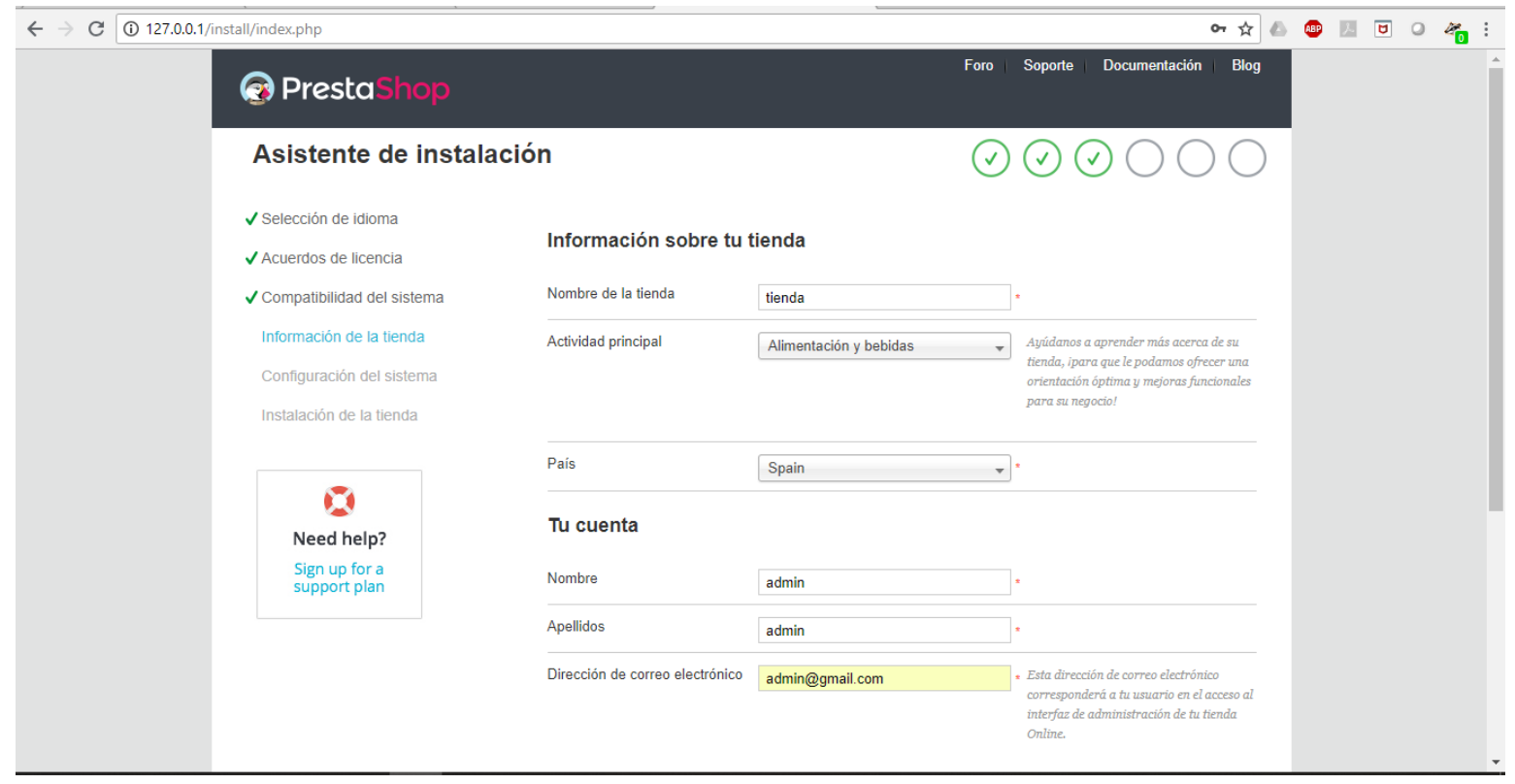

Figura 38. Instalación de la tienda, paso 6

Fuente: elaboración propia

\section{Dar clic en el botón "Siguiente".}

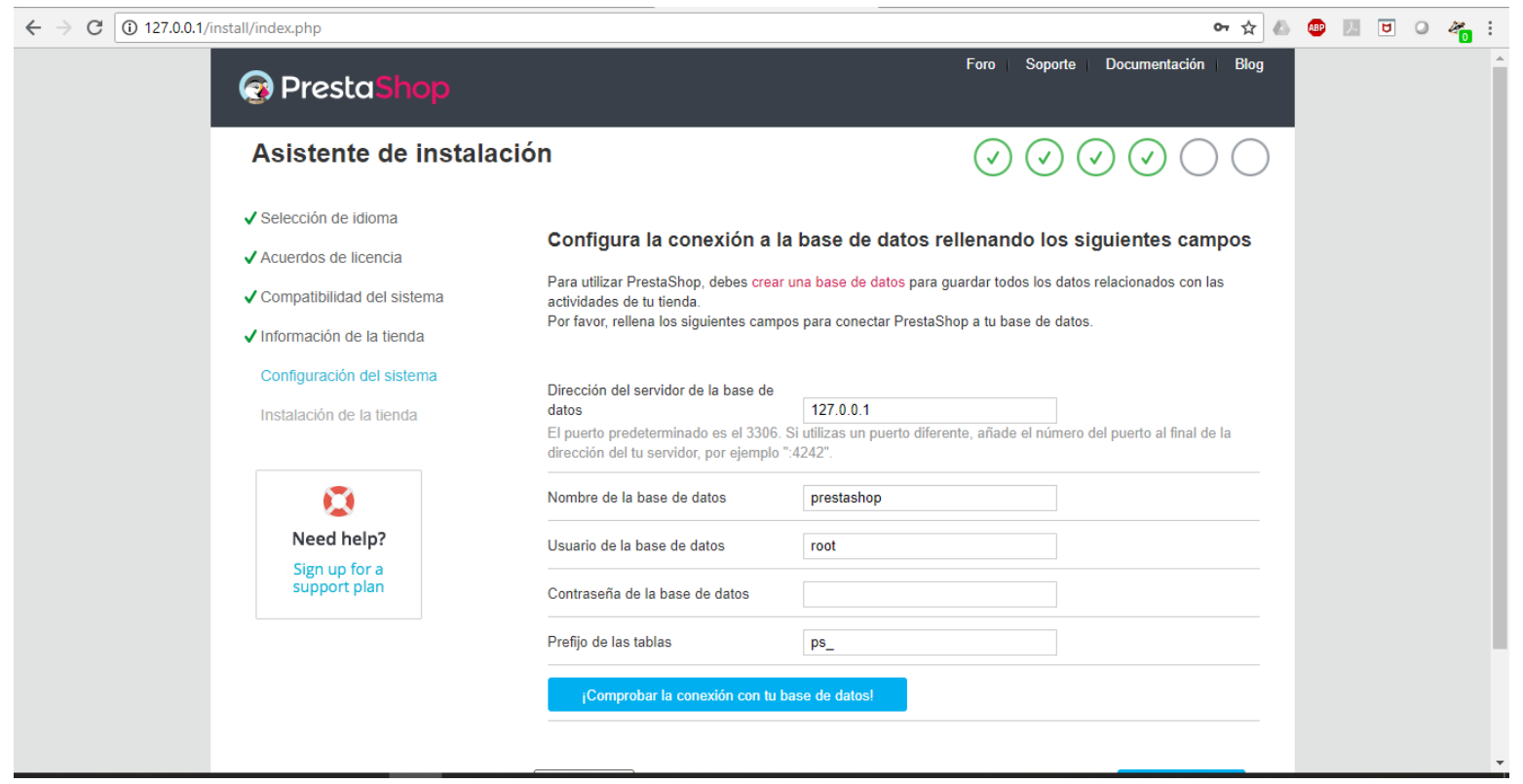

Figura 39. Instalación de la tienda, paso 7

Fuente: elaboración propia 
En "Bases de datos" se coloca el nombre de "comercio" en "Nombre de la base de datos", y los demás campos se dejan igual. Se da clic en el botón "Siguiente".

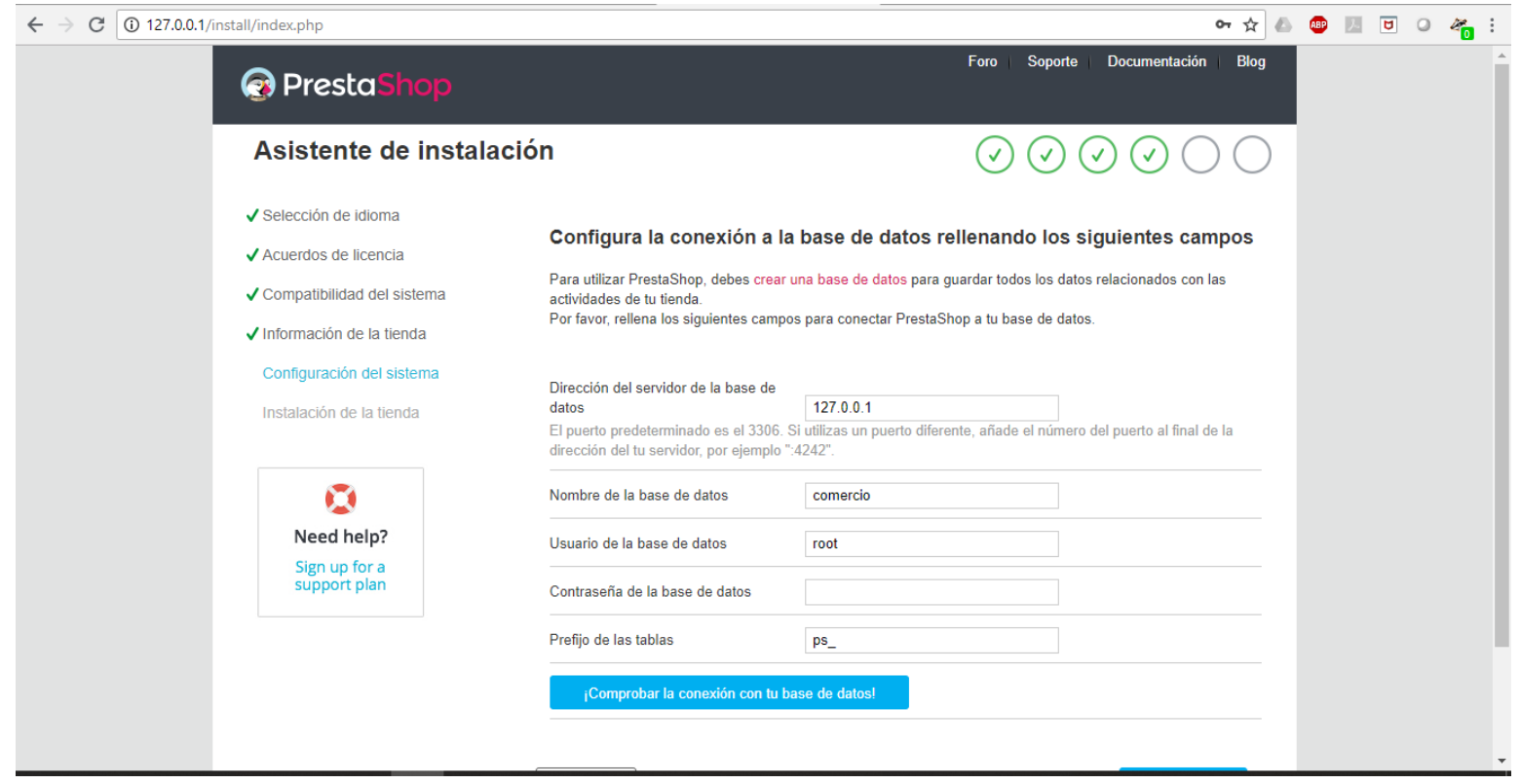

Figura 40. Instalación de la tienda, paso 8

Fuente: elaboración propia

Después de esto empieza la instalación.

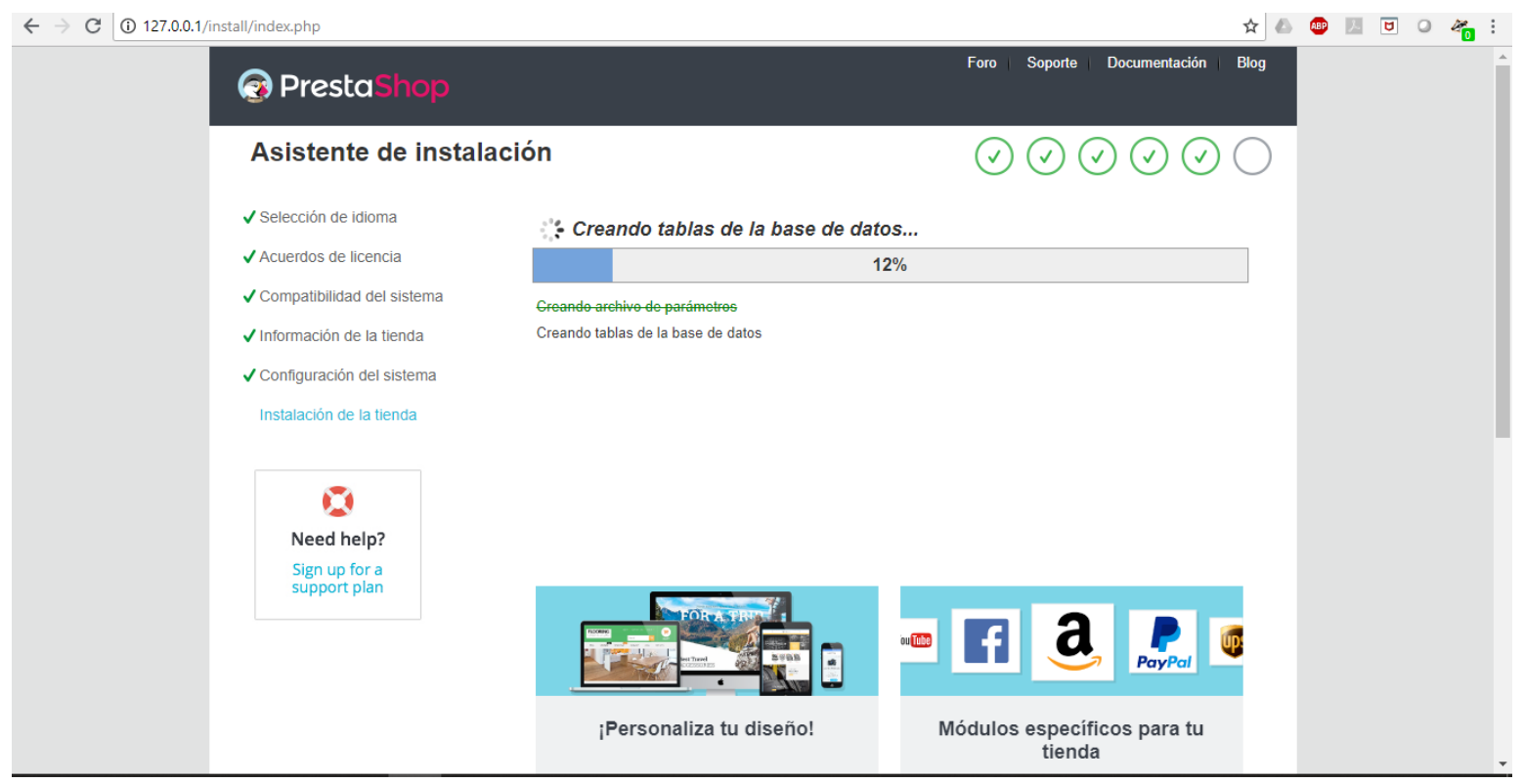

Figura 41. Instalación de la tienda, paso 9

Fuente: elaboración propia 
Luego, finalizará la instalación.

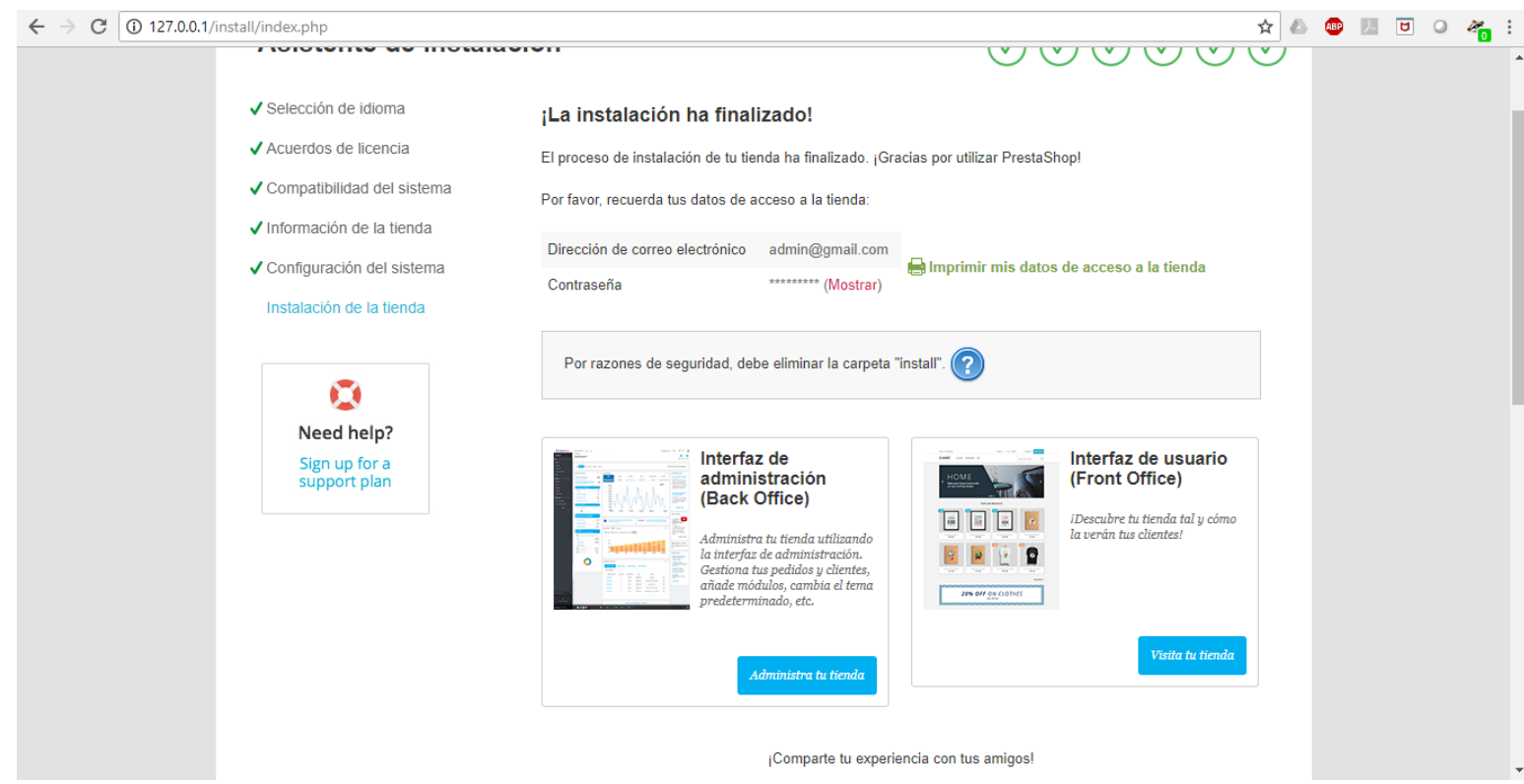

Figura 42. Finalización de la instalación

Fuente: elaboración propia

Dar clic en la opción "Administra tu tienda".

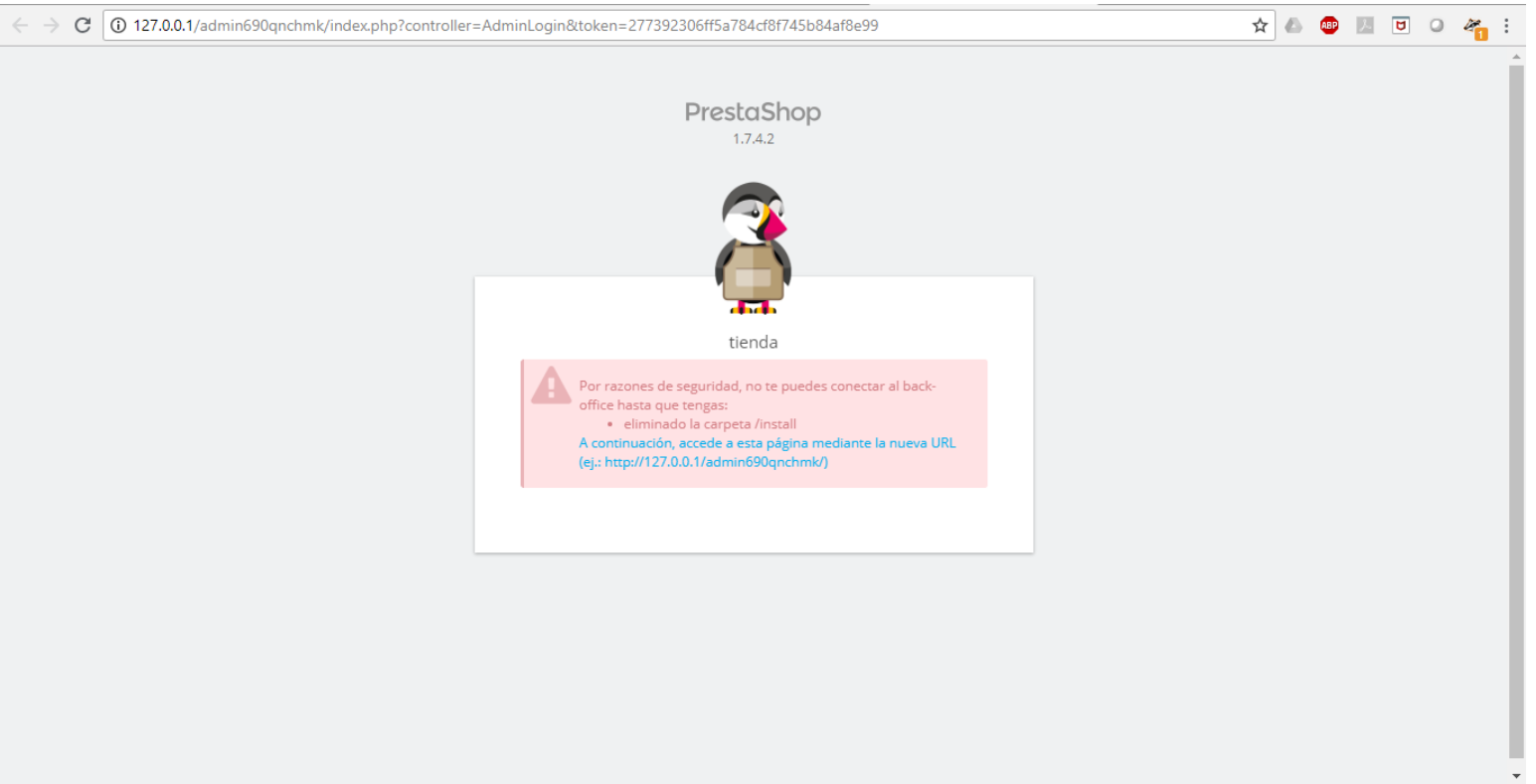

Figura 43. Mensaje para borrado de carpeta "Install"

Fuente: elaboración propia 
Según el mensaje, se debe borrar la carpeta "Install" en la ruta que se muestra en la figura 44 , antes de dar clic al enlace.

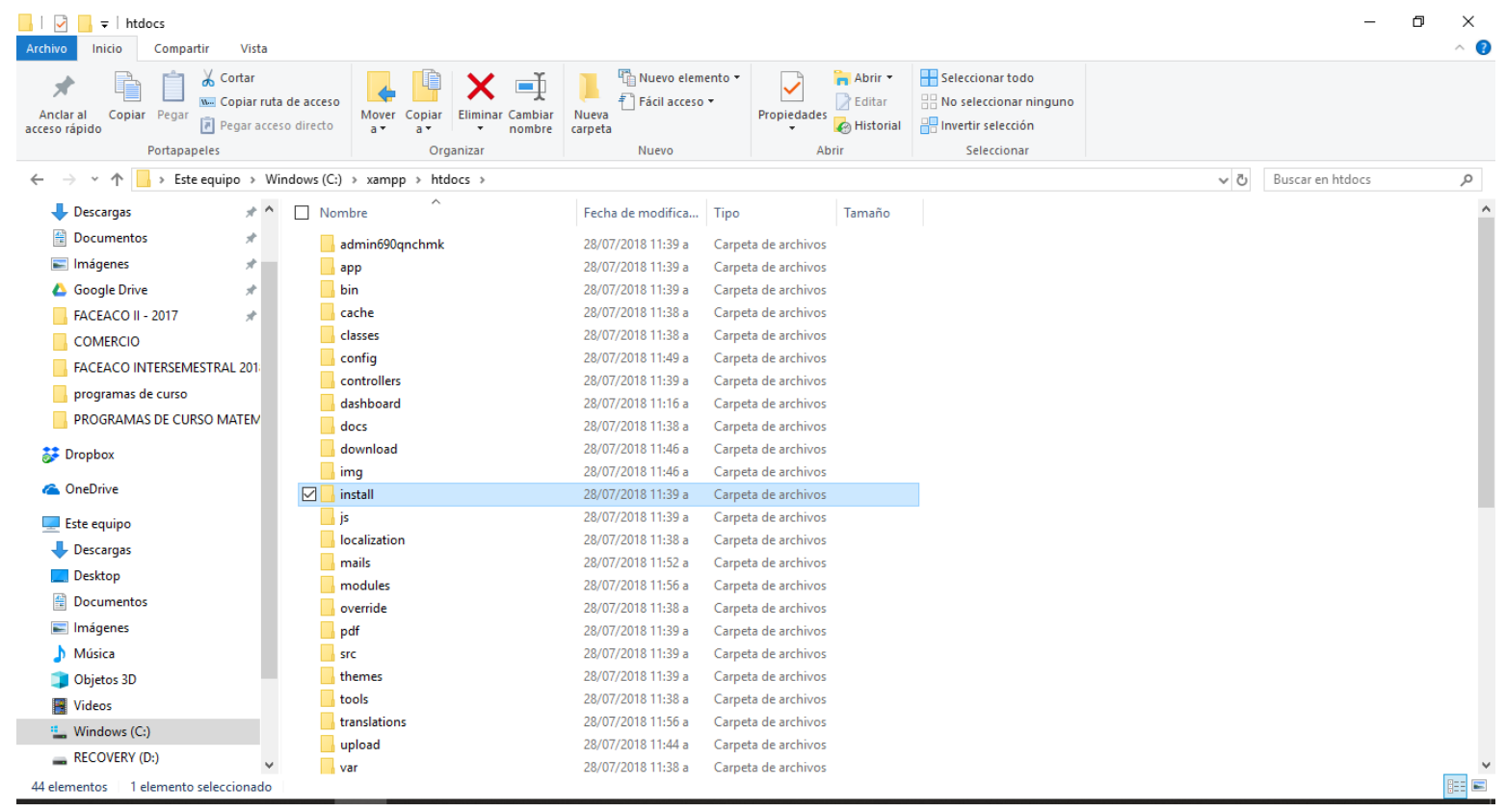

Figura 44. Ruta para la eliminación de la carpeta "Install"

Fuente: elaboración propia

Al borrar la carpeta "Install" y dar clic en la URL de la figura 37, se procede a ingresar el correo electrónico y la contraseña creada en el momento de la instalación de la tienda.

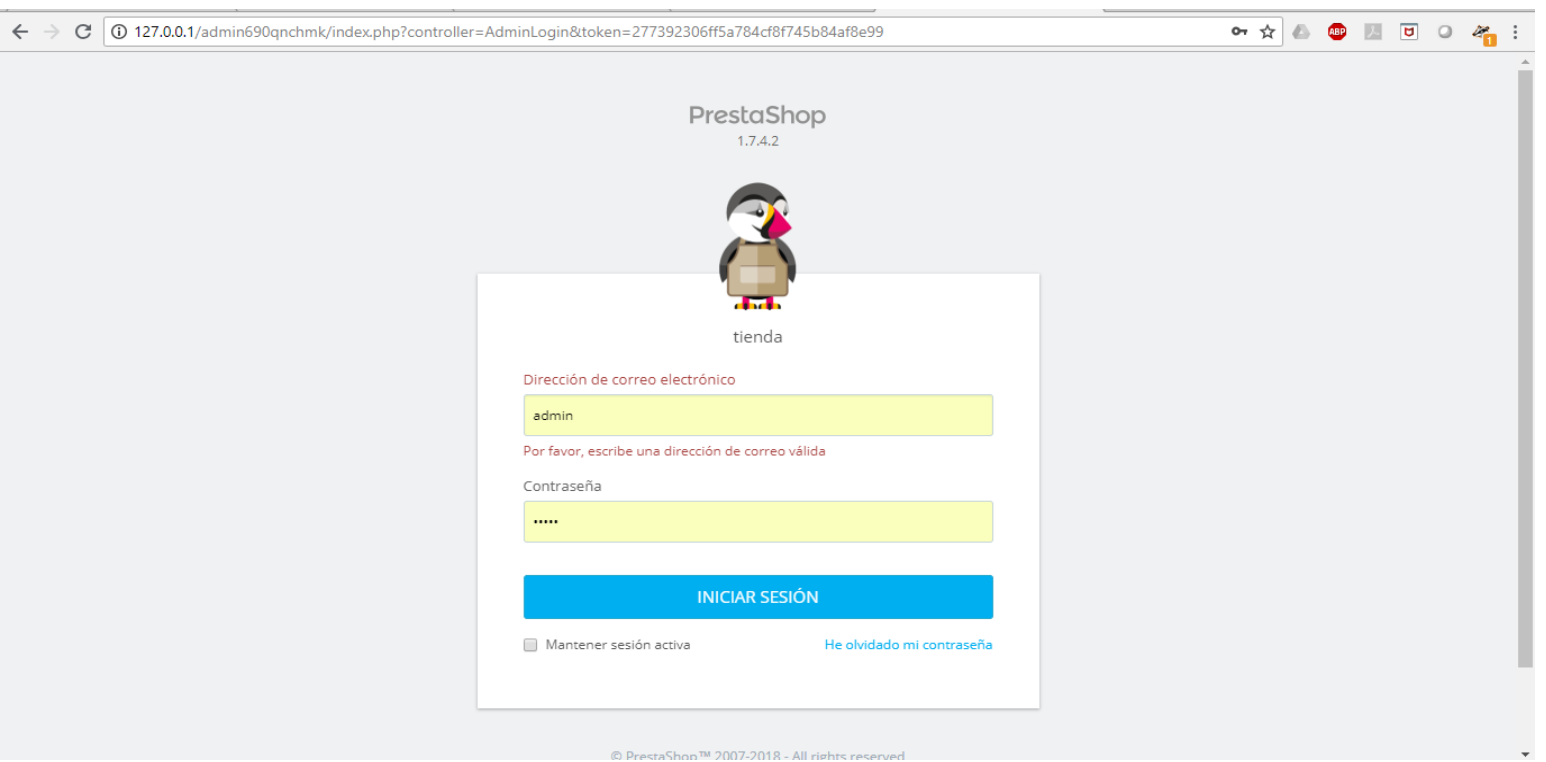

Figura 45. Solicitud de logueo para entrar a la parte administrativa de la tienda Fuente: elaboración propia 


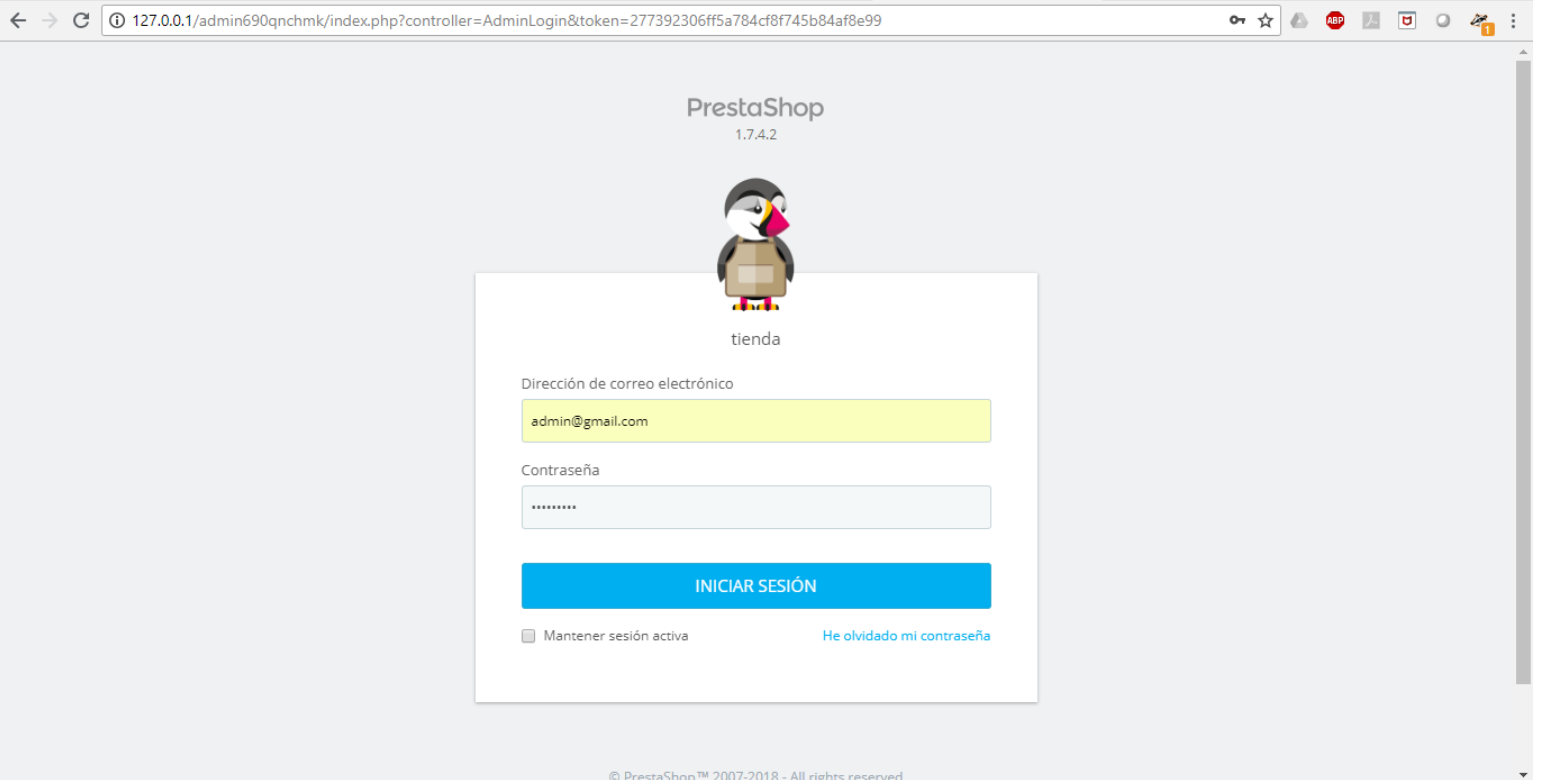

Figura 46. Datos para el logueo a la parte administrativa Fuente: elaboración propia

Se reflejan los datos ingresados, luego, dar clic en "Iniciar sesión".

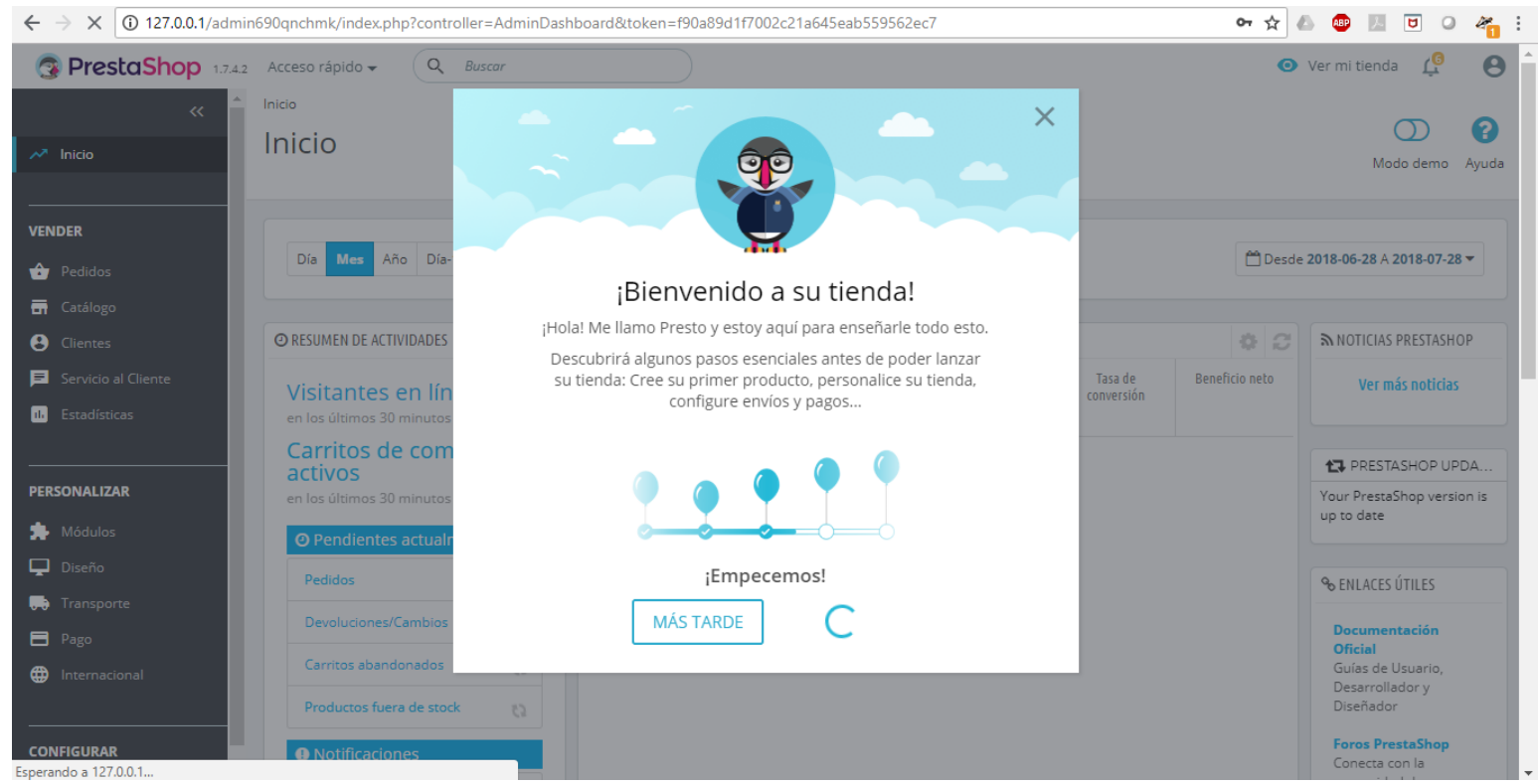

Figura 47. Mensaje de bienvenida a la parte administrativa de la tienda Prestashop Fuente: elaboración propia 
Dar clic en la opción más tarde en la bienvenida de la parte administrativa para entrar.

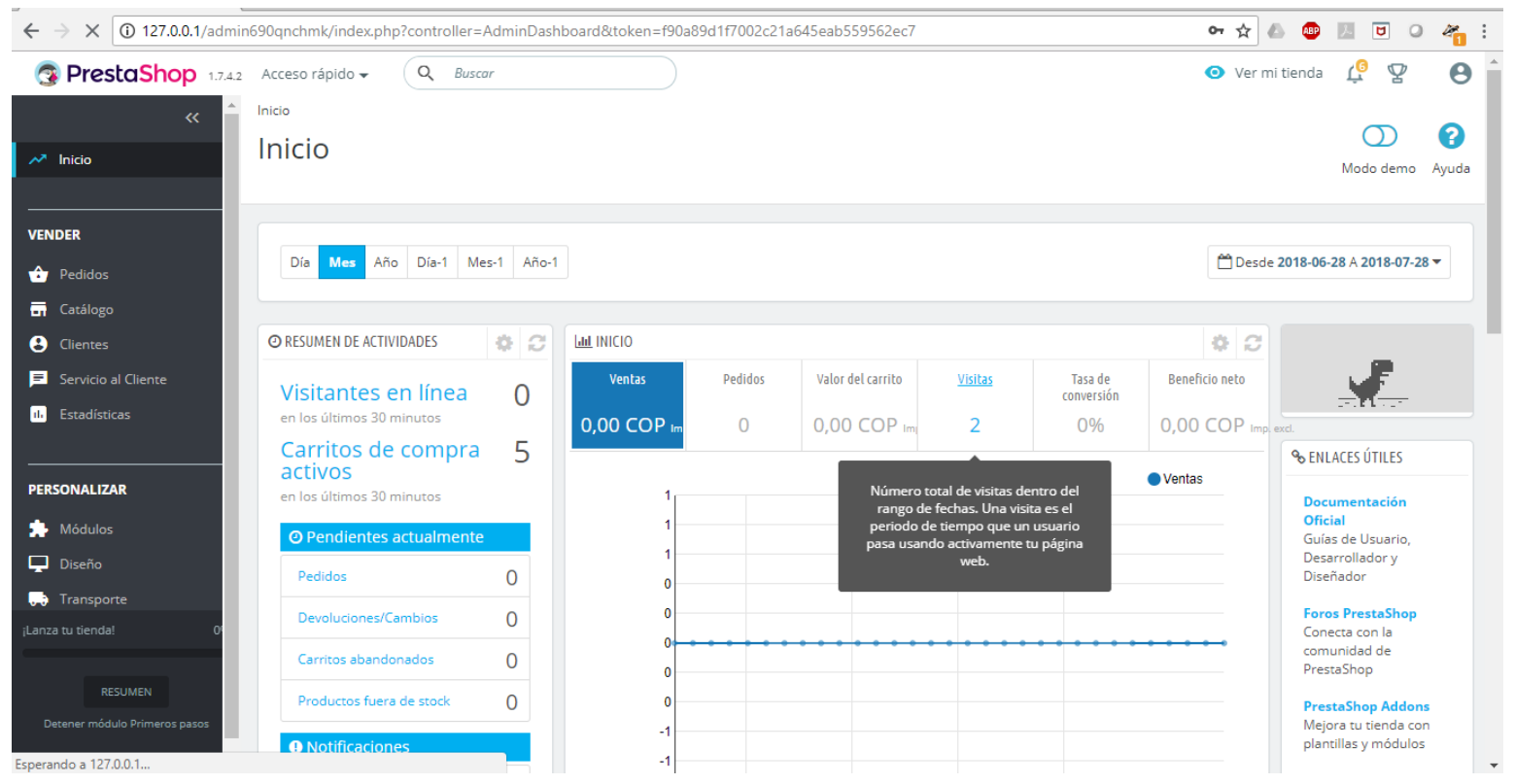

Figura 48. Parte administrativa de la tienda Prestashop Fuente: elaboración propia

Aquí, en la parte administrativa, se ajusta la configuración. En este caso siguiendo las directrices de la matriz de valoración para la entrega del proyecto de fin de semestre.

Luego, volver a la página de finalización de la instalación de la tienda y dar clic en "Visita tu tienda". 


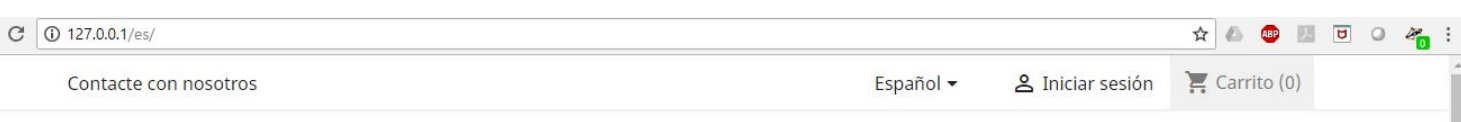

\begin{tabular}{l|l|l|} 
my store & CLOTHES ACCESORIOS ART
\end{tabular}

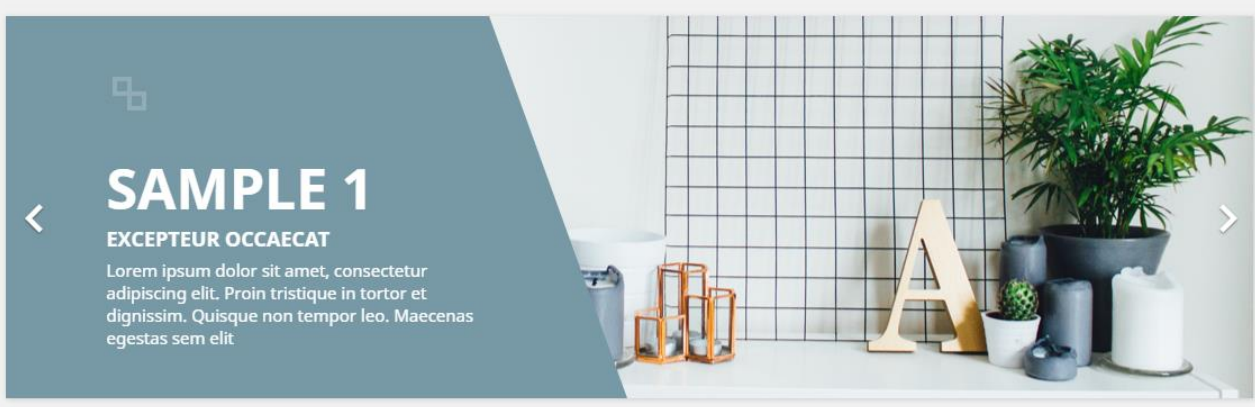

PRODUCTOS DESTACADOS

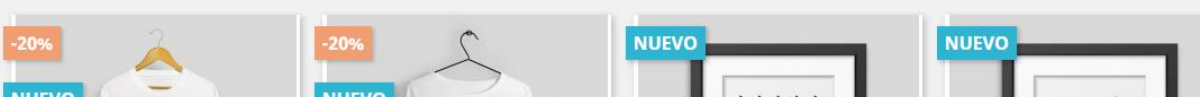

Figura 49. Front end de la tienda electrónica

Fuente: elaboración propia

Este es, por defecto, el front end que ve el usuario o consumidor, pero los estudiantes lo ajustan al diseño de su proyecto final. 


\section{Trabajo final para los estudiantes}

Después de la instalación, los estudiantes ajustarán la tienda para la presentación de proyecto final, según la matriz de valoración que se presenta en la tabla 1.

Tabla 1

Matriz de valoración para la tienda electrónica

\begin{tabular}{|c|c|c|}
\hline Matriz de valoración & Requerimientos mínimos & Valor \\
\hline Configuración de medios de pago & $\begin{array}{l}\text { Configurar por lo menos } \\
\text { seis formas de pago dife- } \\
\text { rentes. La información que } \\
\text { se proporcione en los me- } \\
\text { dios de pago debe ser clara } \\
\text { y coherente con el medio } \\
\text { de pago. }\end{array}$ & 7 \\
\hline Cantidad de productos & $\begin{array}{l}\text { 220. Nota: la descripción } \\
\text { de los productos debe estar } \\
\text { en el idioma inglés y espa- } \\
\text { ñol. }\end{array}$ & 10 \\
\hline $\begin{array}{l}\text { Numero de fabricantes o proveedo- } \\
\text { res }\end{array}$ & 25 & 5 \\
\hline Categorías (ordenadas) & Mínimo ocho. & 5 \\
\hline Configuración de ofertas & Mínimo 60 & 3 \\
\hline Subcategorías (ordenadas) & $\begin{array}{l}\text { Mínimo } 16 \text { (dos por cate- } \\
\text { goría) }\end{array}$ & 5 \\
\hline
\end{tabular}




\begin{tabular}{|l|c|c|}
\hline Moneda e impuesto & Colombiano & 7 \\
\hline Proceso de compra (sin errores) & & 15 \\
\hline $\begin{array}{l}\text { Información de los productos (clara y } \\
\text { acorde a los productos vendidos) }\end{array}$ & 13 \\
\hline Propiedad del tema (sustentación) & & 10 \\
\hline $\begin{array}{l}\text { Presentación (imágenes, ortografía, } \\
\text { letra, formato etc.). }\end{array}$ & 5 \\
\hline Manual de configuración y uso (de la & En CD & \\
\hline tienda desarrollada) & & 15 \\
\hline Total & & 100 \\
\hline
\end{tabular}

Tener en cuenta:

* La tienda debe estar organizada. Coherencia entre categorías, subcategorías

* Temática de la tienda electrónica

Temáticas que no se pueden utilizar: tecnología (celulares, pc, etc.), motos, carros, zapatos, ropa.

Fuente: elaboración propia 


\section{Referencias}

Calcaneo I. (2018). Las 5 plataformas más usadas para crear una tienda online. Gananci.com. Recuperado de https://gananci.com/plataformas-crear-tiendaonline/

Godaddy. (2018). La empresa. Godday.com. Recuperado de https://co.godaddy.com/company/about?isc=goflco30

Jimdo. (2018). Información general de Jimdo. Jimdo.com. Recuperado de https://es.jimdo.com/prensa/comunicados-de-prensa/datos-generales-jimdo/

Jumpseller. (2018). Nosotros. Jumpseller.co. Recuperado de https://jumpseller.co/about/

Laudon, K. y Guercio, C. (2017). E-commerce (13 ${ }^{\text {a }}$ ed.). Editorial Pearson.

Marketing Digital. (s. f). Actores y tipos de comercio electrónico. UOC.EDU. Recuperado de http://cv.uoc.edu/UOC/a/moduls/90/90_574b/web/main/m8/c5/2.html

Merodio H. (2018). Qué es Shopify. OHDIGITAL.eu. Recuperado de https://ohdigital.eu/blogs/aprender-shopify-en-espanol/que-es-shopify

Ortega J. (2018). ¿Qué es PrestaShop y cómo crear gratis una tienda online paso a paso con PrestaShop? El blog de Jose Fachin. Recuperado de https://josefacchin.com/prestashop/

Peña E. (2016). ¿Qué es una tienda virtual? Vexsoluciones.com. Recuperado de https://www.vexsoluciones.com/tecnologias/que-es-una-tienda-virtual/

Turban, E. y Volonino, L. (2010). Information technology for management ( $\left.7^{\mathrm{a}} \mathrm{ed}.\right)$. Editorial Wiley. 
Webnode. (2018). Sobre nosotros. Webnode.com. Recuperado de https://www.webnode.com.co/sobre-nosotros/

Wikipedia. (2018). XAMPP. Wikipedia.org. Recuperado de https://es.wikipedia.org/wiki/XAMPP 


\section{Parámetros para la elaboración y presentación del informe}

El grupo de estudiantes deberá socializar la tienda implementada y evidenciar el dominio del tema. Adicionalmente, entregará un manual que contemplará los pasos para:

- Crear un producto.

- Crear una categoría.

- Crear una subcategoría.

- Crear la moneda.

- Crear el impuesto.

- Activar medios de pago.

- Activar medios de transporte.

- Registrar proveedores o fabricantes.

- Crear ofertas o promociones.

Este manual debe entregarse en PDF, en un CD. Los pasos deben presentarse sobre la tienda que los estudiantes han creado. 
